\title{
Water Withdrawals and Trends from the Floridan Aquifer System in the Southeastern United States, 1950-2000
}

By Richard L. Marella and Marian P. Berndt

A contribution of the National Water Quality Assessment (NAWQA) Program

U.S. Geological Survey Circular 1278 


\title{
U.S. Department of the Interior \\ Gale A. Norton, Secretary
}

\section{U.S. Geological Survey \\ P. Patrick Leahy, Acting Director}

\section{U.S. Geological Survey, Reston, Virginia: 2005}

\author{
For sale by U.S. Geological Survey, Information Services \\ Box 25286, Denver Federal Center \\ Denver, CO 80225 \\ For more information about the USGS and its products: \\ Telephone: 1-888-ASK-USGS \\ World Wide Web: http://www.usgs.gov/
}

\begin{abstract}
Any use of trade, product, or firm names in this publication is for descriptive purposes only and does not imply endorsement by the U.S. Government.

Although this report is in the public domain, permission must be secured from the individual copyright owners to reproduce any copyrighted materials contained within this report.
\end{abstract}

Marella, R.L., and Berndt, M.P., 2005, Water withdrawals and trends from the Floridan aquifer system in the southeastern United States, 1950-2000: U.S. Geological Survey Circular 1278, 20 p.

\section{Library of Congress Cataloging-in-Publication Data}

Marella, Richard L.

Water withdrawals and trends from the Floridan aquifer system in the Southeastern United States, 1950-2000 /

by Richard L. Marella and Marian P. Berndt.

p. cm. -- (U.S. Geological Survey circular ; 1278)

Includes bibliographical references.

ISBN 0-607-96885-0

1. Water withdrawals--Gulf States. 2. Floridan Aquifer. I. Berndt, Marian P. II. Title. III. Series. TD223.5.M37 2005

$333.91^{\prime} 0413^{\prime} 0975--d c 22$

2005046390 


\section{Contents}

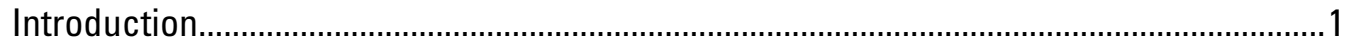

National Water-Quality Assessment Program ..............................................................

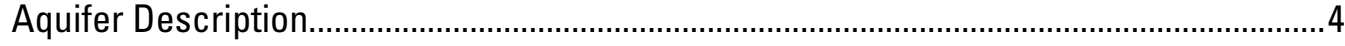

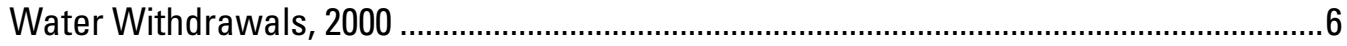

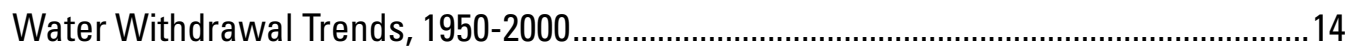

Water Quantity and Quality Concerns .............................................................................

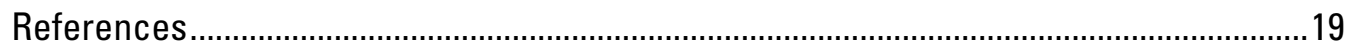

\section{Figures}

1. Map showing general extent of the Floridan aquifer system .............................. 1

2. Map showing location of principal aquifers selected for regional assessment by the National Water-Quality Assessment Program

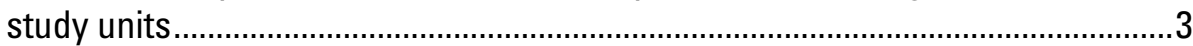

3. Diagram showing sequence of aquifers in the southeastern

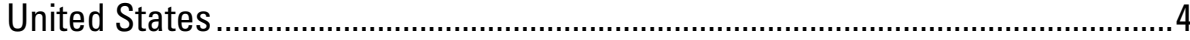

4. Map showing confinement of the Upper Floridan aquifer system ......................5

5. Chart showing water withdrawals from the Floridan aquifer

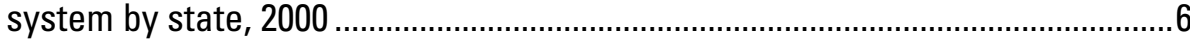

6. Chart showing water withdrawals from the Floridan aquifer system by the largest public-water suppliers, 2000 ...........................................

7. Chart showing percentage of water withdrawals from the

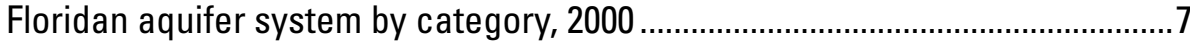

8. Map showing water withdrawals from the Floridan aquifer

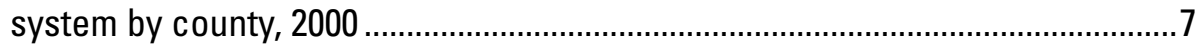

9. Map showing extent of the Floridan aquifer system in the southeastern United States by county 13

10. Chart showing total water withdrawals from the Floridan aquifer system, 1950-2000

11. Graph showing water withdrawals from the Floridan aquifer system by category, 1950-2000 15

12. Graph showing fluctuations of ground-water levels in selected wells in the Upper Floridan aquifer. 


\section{Tables}

1. Water withdrawals from the Floridan aquifer system by county, 2000 .

2. Water withdrawals from the Floridan aquifer system by category, 1950-2000.

\section{Conversion Factors and Datums}

\begin{tabular}{lcl}
\hline Multiply & By & To obtain \\
\hline & Length & \\
\hline inch (in.) & 2.54 & centimeter $(\mathrm{cm})$ \\
inch (in.) & 25.4 & millimeter $(\mathrm{mm})$ \\
foot (ft) & 0.3048 & meter $(\mathrm{m})$ \\
mile (mi) & 1.609 & kilometer $(\mathrm{km})$ \\
\hline & Area & \\
\hline square mile $\left(\mathrm{mi}^{2}\right)$ & 259.0 & hectare $(\mathrm{ha})$ \\
square mile $\left(\mathrm{mi}^{2}\right)$ & 2.590 & square kilometer $\left(\mathrm{km}^{2}\right)$ \\
\hline & Flow rate & \\
\hline foot per year $(\mathrm{ft} / \mathrm{yr})$ & 0.3048 & meter per year $(\mathrm{m} / \mathrm{yr})$ \\
cubic foot per second $(\mathrm{ft} 3 / \mathrm{s})$ & 0.02832 & cubic meter per second $\left(\mathrm{m}^{3} / \mathrm{s}\right)$ \\
million gallons per day $(\mathrm{Mgal} / \mathrm{d})$ & 0.04381 & cubic meter per second $\left(\mathrm{m}^{3} / \mathrm{s}\right)$ \\
inch per year (in/yr) & 25.4 & millimeter per year $(\mathrm{mm} / \mathrm{yr})$ \\
\hline
\end{tabular}




\section{Introduction}

The Floridan aquifer system in the southeastern United States is one of the most productive aquifers in the world (Miller, 1990). This aquifer system underlies an area of about 100,000 square miles in southern Alabama, eastern and southern Georgia, southeastern Mississippi, southern South Carolina, and all of Florida (fig. 1). The Floridan aquifer system is the primary source of water for nearly 10 million people and supports agriculture, industry, and tourism throughout most of the region. In most areas, water from this aquifer is potable and needs very little treatment before use. However, in southern Florida (south of Lake Okeechobee), northwestern Florida and southern Alabama and Mississippi (Pensacola and westward), and eastern South Carolina, water in the aquifer system generally is not potable.

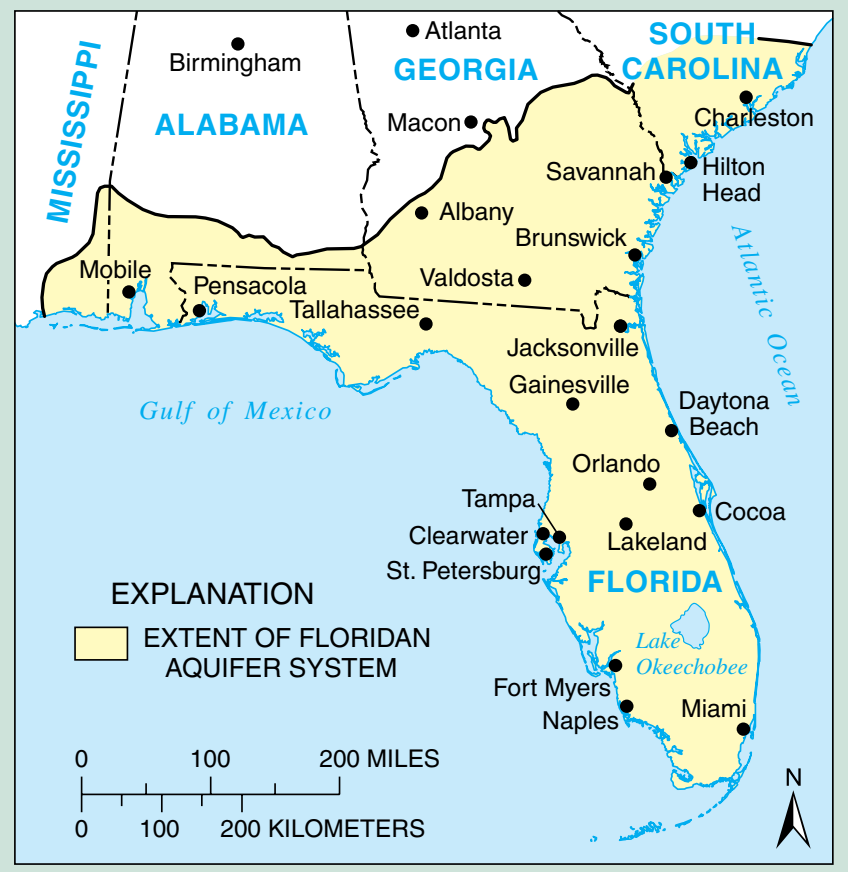

Figure 1. General extent of the Floridan aquifer system. (Modified from Miller, 1990; and Aucott and others, 1986.)
The purpose of this report is to:

- Provide a general description of the Floridan aquifer system;

- Discuss water withdrawals by category for 2000 ;

- Highlight trends in water withdrawals between 1950 and 2000; and

- Provide a brief summary on the effects that human impacts have on the Floridan aquifer system.

Water from the Floridan aquifer system is generally potable and needs very little treatment before use.

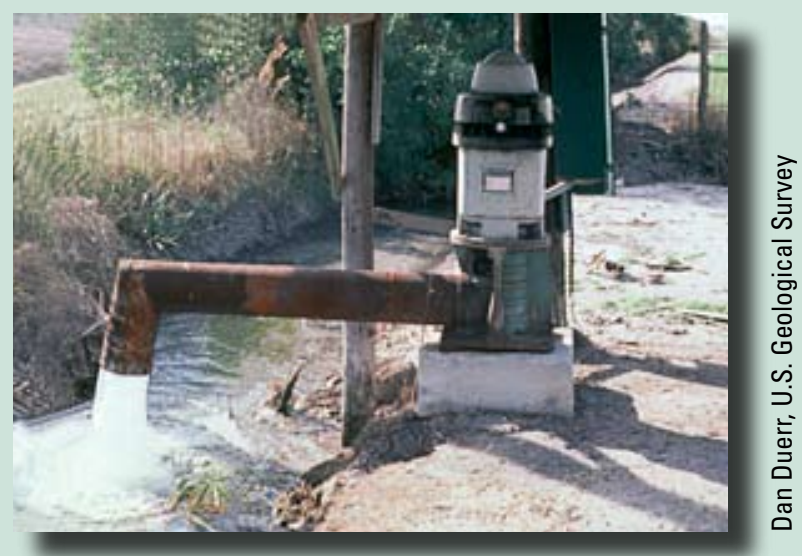

Irrigation well in Hillsborough County, Florida.

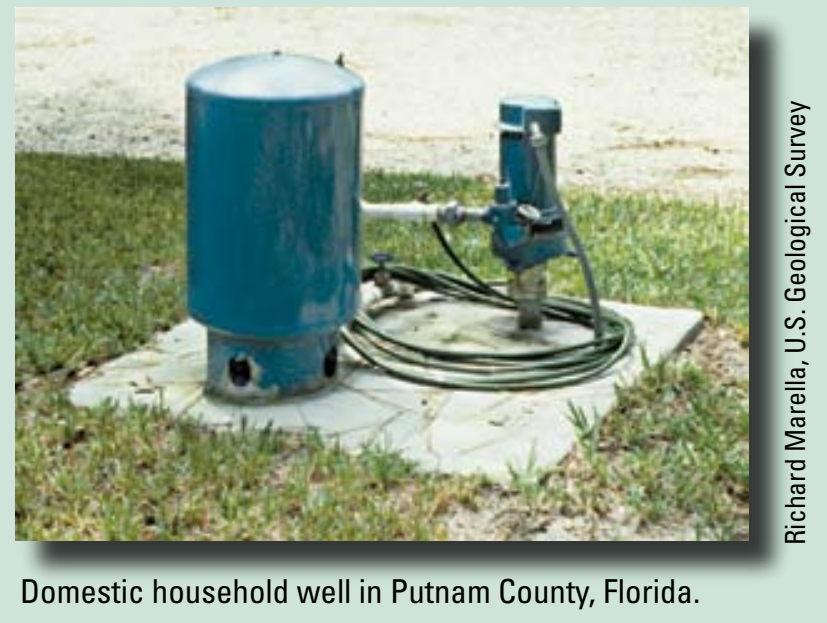




\section{National Water-Quality Assessment Program}

This report is a product of the U.S. Geological Survey (USGS) National Water-Quality Assessment Program regional synthesis of ground-water quality by principal aquifer study. The Floridan aquifer system is one of the principal aquifers in the United States selected for regional synthesis of ground-water quality and study between 2001-2010 (fig. 2).

The National Water-Quality Assessment (NAWQA) Program is a primary source for long-term, consistent, nationwide information on the quality of ground water, streams, and aquatic ecosystems. The goals of NAWQA are to assess the status and trends of the water quality of the Nation and to understand the factors that affect water quality (Gilliom and others, 2001). Major aquifers and river basins define the 42 NAWQA study units (http://water.usgs.gov/nawqa). Within the individual study units, information on water chemistry, hydrology, land use, stream habitat, and aquatic life is collected and analyzed. Analysis at the study unit scale provides assessment of local factors that affect water quality. NAWQA data from the individual study units also are analyzed nationally to provide syntheses of the national occurrence and distribution of water quality. The large variability in hydrogeology throughout the Nation, however, commonly makes national assessment of ground-water quality challenging. For this reason, regional synthesis of ground-water quality by principal aquifer is an integral part of the NAWQA program during the second decade of studies (2001-2010). The Floridan aquifer system lies beneath five NAWQA study units - the Apalachicola-Chattahochee-Flint River Basins, the Georgia-Florida Coastal Plain Drainages, the Mobile River Basin, the Santee River Basin and Coastal Drainages, and the Southern Florida Drainages (fig. 2).

About 800 springs discharge water from the Floridan aquifer system and many are used for recreation purposes.

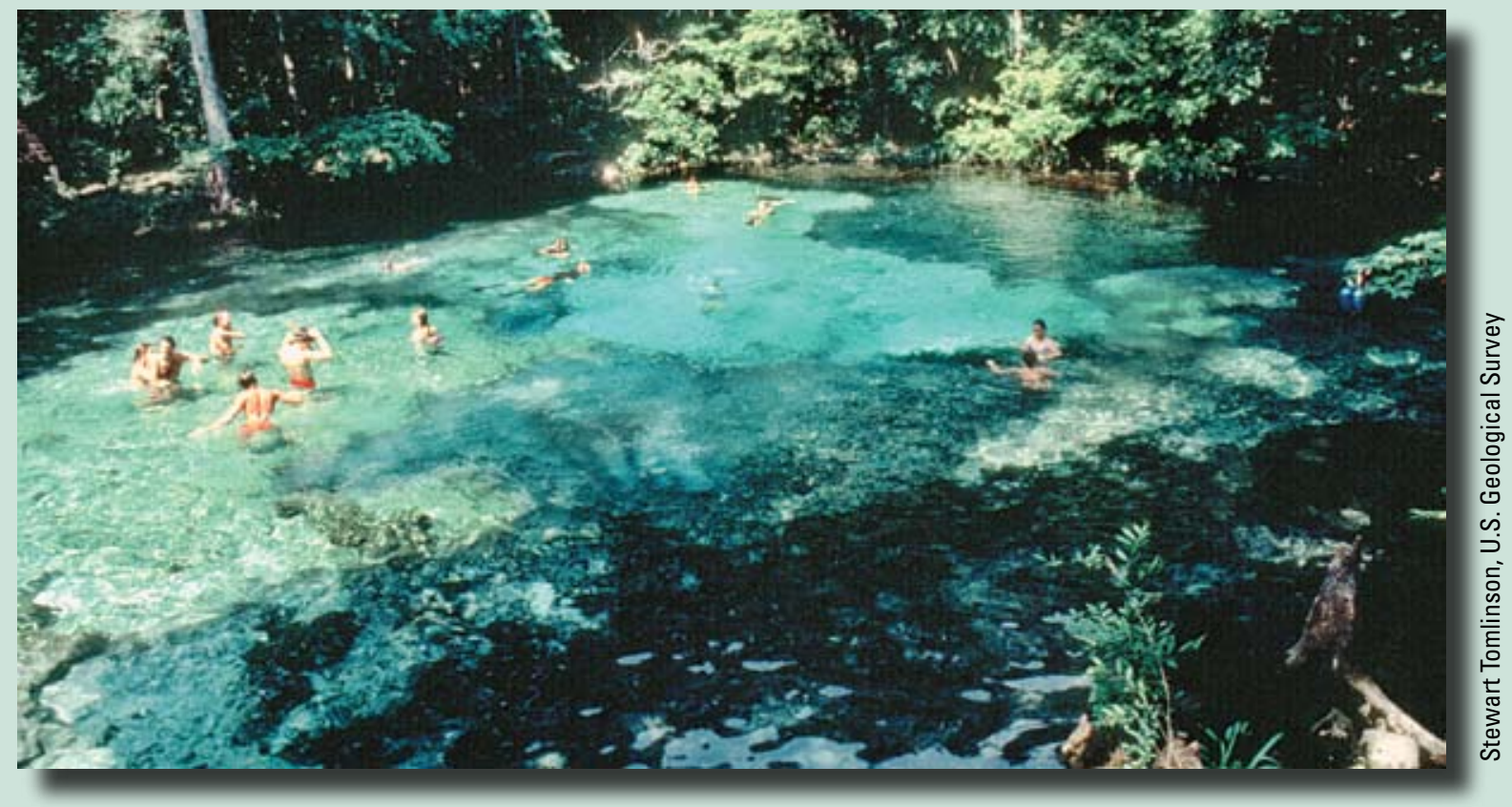

Ginnie Springs (near Gainesville, Florida) is a popular swimming spot during the summer months. 


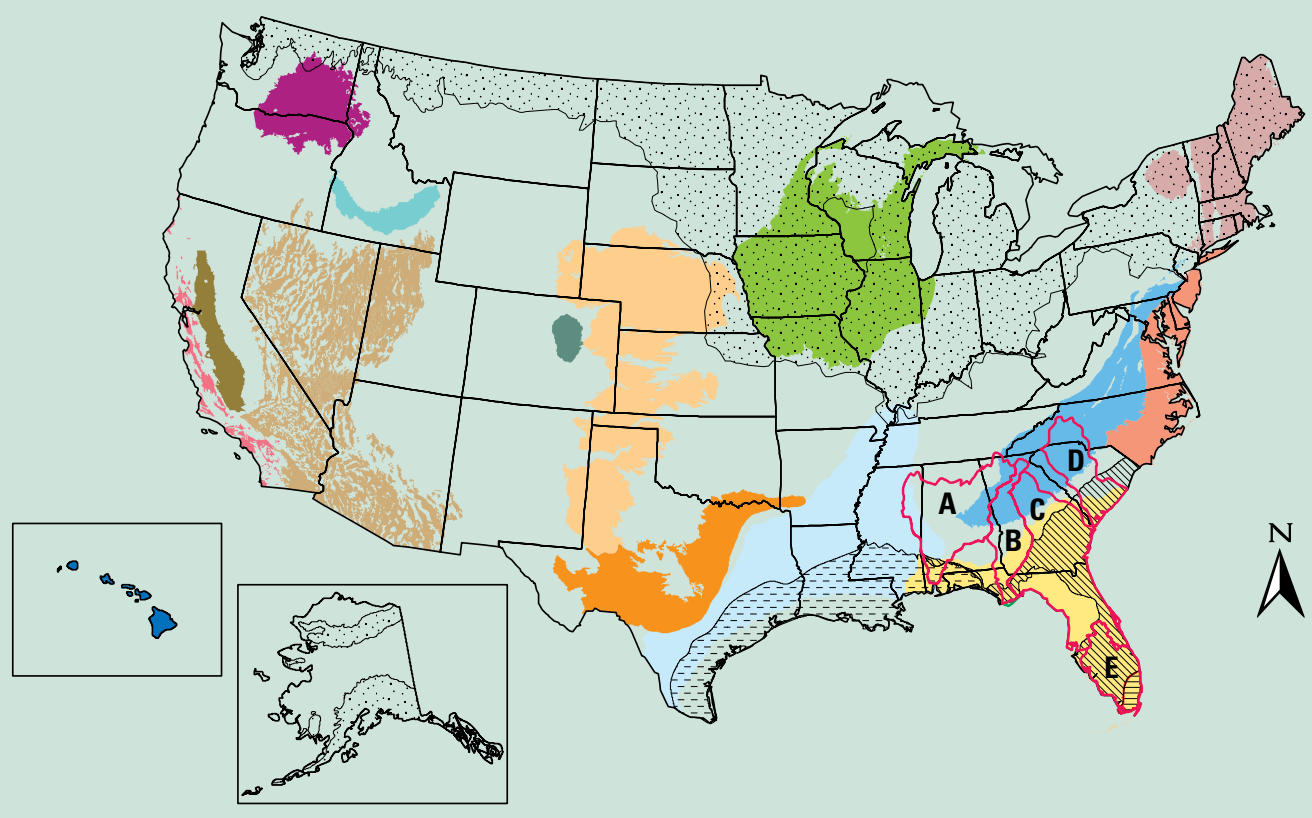

\section{EXPLANATION}

Principal (or other) Aquifers

Hawaiian volcanic-rock aquifers

Aquifers composed of glacial deposits

California Coastal Basin aquifers

Central Valley aquifer system

Columbia Plateau basin-fill and basaltic-rock aquifers ${ }^{1}$

Snake River Plain basin-fill and basaltic-rock aquifers ${ }^{1}$

Basin and Range basin-fill and carbonate-rock aquifers ${ }^{1}$

Denver Basin aquifer system

High Plains aquifer

Edwards-Trinity aquifer system $\square$ Cambrian-Ordovician aquifer system

$\square$ Mississippi embayment-Texas coastal uplands aquifer system ${ }^{1}$

$-=-$ Coastal Lowlands aquifer system $^{2}$

$\square$ Floridan aquifer system

Surficial aquifer system

Biscayne aquifer

$\square$ Piedmont and Blue Ridge crystalline-rock and carbonate-rock aquifers ${ }^{1}$

$\square$ Northern Atlantic Coastal Plain aquifer system

$\square$ New York and New England crystalline-rock aquifers ${ }^{3}$

\section{NAWQA Study Units overlying the Floridan aquifer system (outlined in red)}

A Mobile River Basin

B Apalachicola-Chattahoochee-Flint River Basins

C Georgia-Florida Coastal Plain Drainages

1 Combinations of principal aquifers.

${ }^{2}$ Referred to as the sand-and-gravel aquifer in Florida.

${ }^{3}$ Not considered principal aquifers (defined as regionally extensive aquifers or aquifer systems that have the potential to be used as a source of potable water). The New York and New England crystalline rocks are, in general, minimally permeable but contain locally productive aquifers that serve domestic supplies.

Source: Modified from U.S. Geological Survey, 2003

Figure 2. Location of principal aquifers selected for regional assessment by the National Water-Quality Assessment Program (NAWQA) study units. The Floridan aquifer system lies beneath five NAWQA study units. 


\section{Aquifer Description}

The Floridan aquifer system is overlain by other aquifer systems in some areas that are used for local water supply. Leakage from these overlying aquifer systems recharges the Floridan aquifer system. These overlying aquifers include the surficial aquifer system, the intermediate aquifer system, the sand-and-gravel (Coastal Lowlands) aquifer, and the Biscayne aquifer (fig. 3). These aquifers are important sources of water supply locally. The sand-and-gravel aquifer is the major source of water in northwestern Florida (Pensacola area) and coastal Alabama (Mobile area); the Biscayne aquifer is the major source of water in southeastern Florida (Miami area); and the intermediate and surficial aquifers are the major sources of water in southwestern Florida (Fort Myers and Naples area).

The Floridan aquifer system is composed of a thick sequence of carbonate rocks (limestone and dolomite) of Tertiary age that range from late Paleocene to early Miocene. The aquifer system generally thickens toward the south from a thin edge near its northern limit in Georgia and South Carolina to more than 3,400 feet in

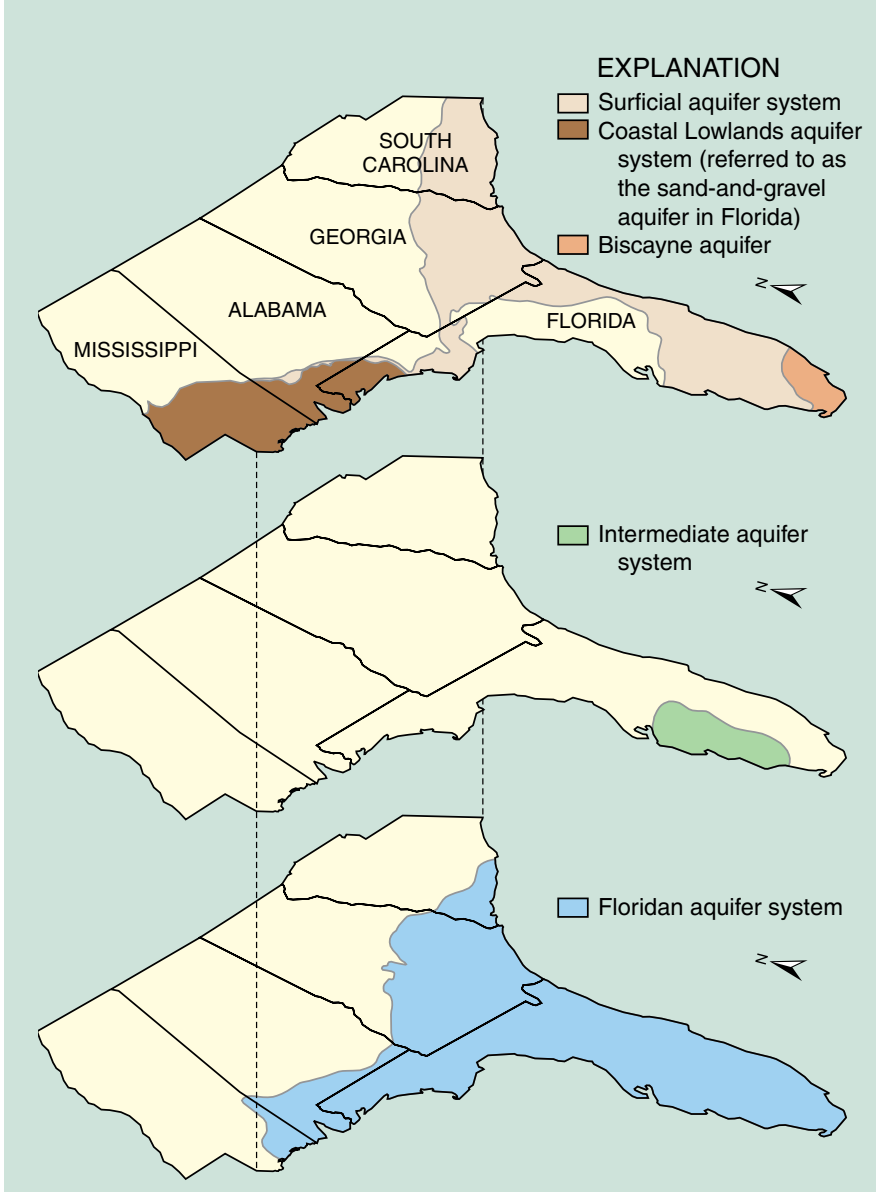

Figure 3. Sequence of aquifers in the southeastern United States. (Modified from Miller, 1990; Renken, 1998.)
The Floridan aquifer system is comprised of limestone and dolomite. In some places, it is close to the land surface.

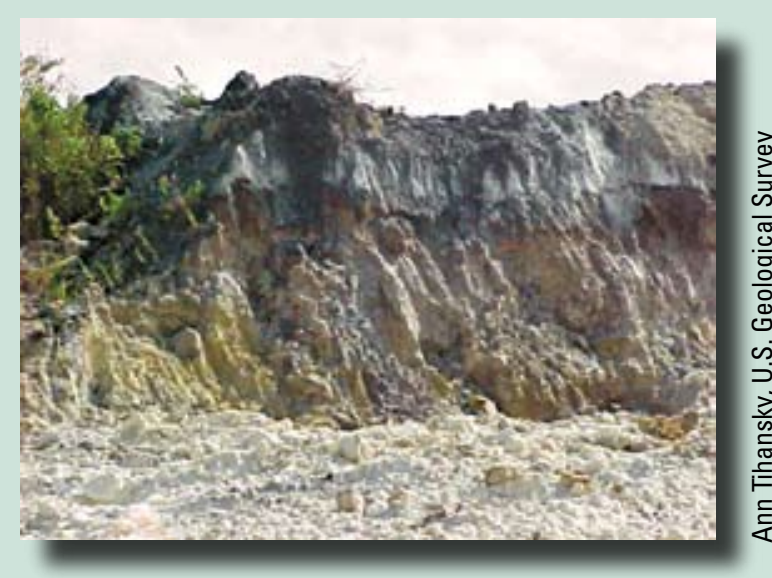

Limestone quarry in Pasco County, Florida.

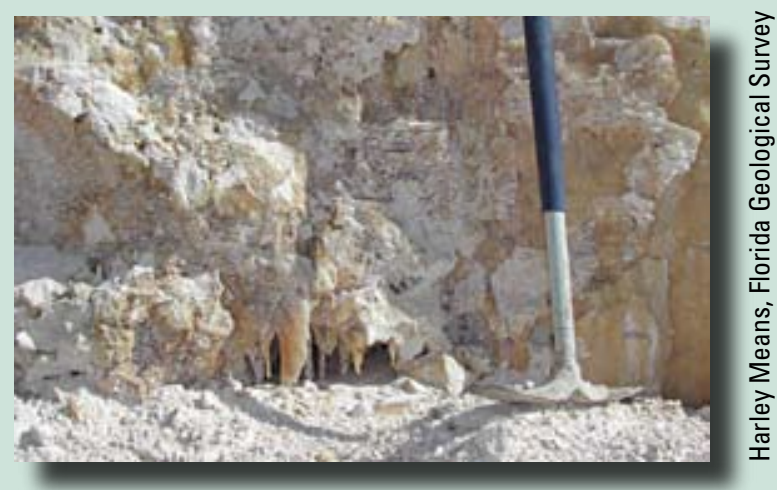

Limestone quarry in Citrus County, Florida. 
southern Florida (Miller, 1990). In most areas, the aquifer system is divided into three units: the Upper Floridan aquifer, the middle confining unit, and the Lower Floridan aquifer. The middle confining unit restricts the movement of water between the Upper and Lower Floridan aquifers. Throughout most of its extent, the Upper Floridan aquifer is overlain by a sequence of sand, clay, and limestone, that ranges in thickness from a few feet in parts of west and north-central Florida to hundreds of feet in southeastern Georgia, northeastern Florida, and the westernmost part of the Florida Panhandle. The sand generally comprises the surficial aquifer system, and the clay and limestone generally comprise the intermediate aquifer system, both of which are confining units to the Upper Floridan aquifer because they are less permeable than the Upper Floridan. The Upper Floridan aquifer is unconfined in western parts of north-central Florida, from north of Tampa to south of Tallahassee and in the Albany, Georgia, area southward into parts of Alabama and Florida (fig. 4). In some areas in southern Florida, the Upper Floridan aquifer is being used for the storage of freshwater (from surface water and the surficial aquifer system) for later recovery and use (Reese, 2002).

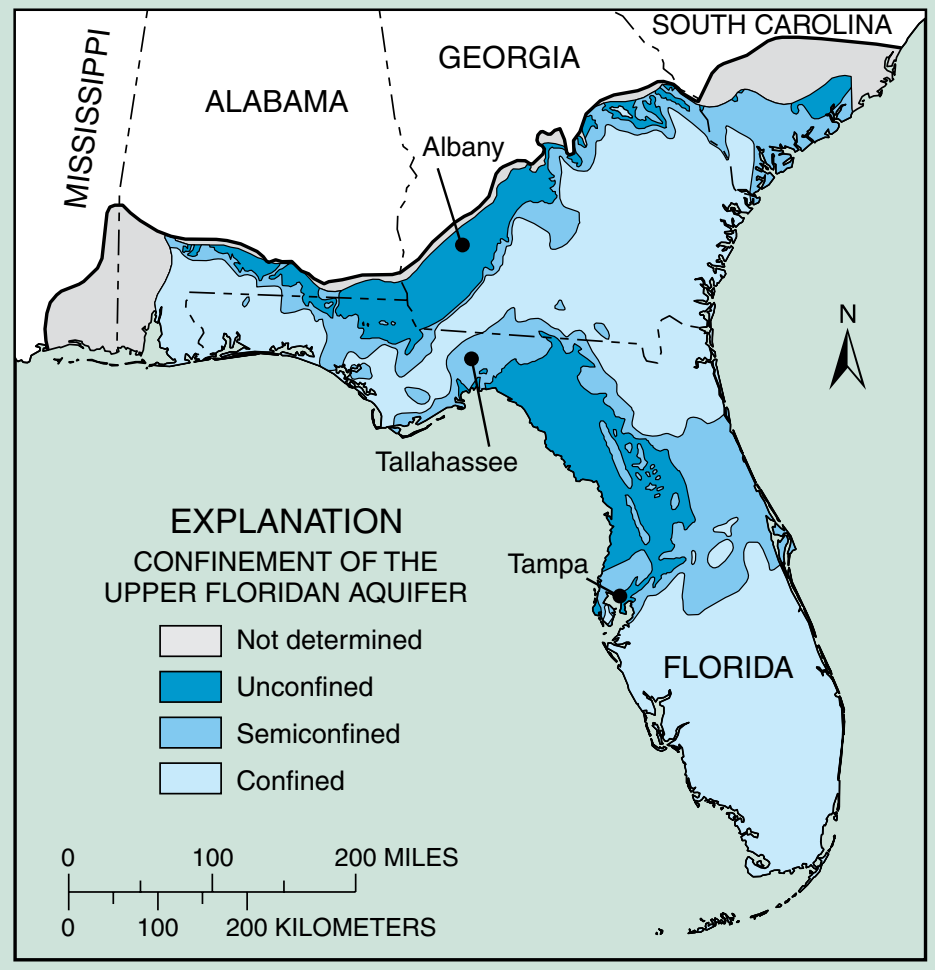

Figure 4. Confinement of the Upper Floridan aquifer system. (Modified from Miller, 1990.)
Recharge to the Upper Floridan aquifer occurs primarily in unconfined or semiconfined (fig. 4) welldrained upland areas characterized by poorly developed stream drainage and many closed depressions (sinkholes). Areas of high recharge (10 to 25 inches per year; Bush and Johnston, 1988; Sepúlveda, 2002) are present in west-central, northern, and western Florida, and in southwestern Georgia. Areas of low recharge (1 inch per year or less; Bush and Johnston, 1988) are present in northeastern Florida and southeastern Georgia, where confining units are greater than 100 feet thick.

Natural discharge from the Upper Floridan aquifer occurs throughout Florida and Georgia, most commonly through springs. A spring is formed when the ground water, which is under pressure, flows out through a natural opening in the ground. Florida has 33 firstmagnitude springs (discharge greater than 100 cubic feet per second or 64.6 million gallons per day), more than any other State (Scott and others, 2004). About 800 springs have been identified within the Floridan aquifer system, 90 percent of which (about 720 springs) are in Florida (Scott and others, 2004). Cumulative discharge from these springs has been estimated at nearly 8 billion gallons per day (Bush and Johnston, 1988). Water discharged from springs provides or augments streamflow throughout central and northern Florida and southern Georgia. Several springs discharge offshore into the Atlantic Ocean or the Gulf of Mexico (Scott and others, 2004). Many springs are used for recreational purposes.

Because it is deeply buried and in many places contains poor-quality water, the Lower Floridan aquifer has not been intensively drilled or tested, so its geologic character is not well known. Ground-water flow in the Lower Floridan aquifer is considered sluggish except where it is directly connected to the Upper Floridan aquifer (Miller, 1986). Some of the thick, low- and high-permeability units within the Lower Floridan aquifer are used in southern Florida for wastewater disposal, whereas some units in central and northern Florida are used as a potable water source. The Lower Floridan aquifer is being developed as a possible water source in many other areas of Florida and Georgia. 


\section{Water Withdrawals, 2000}

An estimated 4,020 million gallons per day (Mgal/d) of water was withdrawn from the Floridan aquifer system in 2000. Nearly 78 percent $(3,125 \mathrm{Mgal} / \mathrm{d})$ of this water was withdrawn in Florida (Marella, 2004) (fig. 5). Lesser amounts were withdrawn in Georgia (825 Mgal/d) (Fanning, 2003), South Carolina (63 Mgal/d) (Whitney Stringfield, U.S. Geological Survey, written commun., January 2003), and Alabama (7 Mgal/d) (Will Mooty, U.S. Geological Survey, written commun., March 2003). No water withdrawals were reported from the Floridan aquifer system in Mississippi during 2000 (David Burt, U.S. Geological Survey, written commun., October 2004).

About 90 percent of the water withdrawn from the Floridan aquifer system was obtained from the Upper Floridan aquifer, which contains potable water in most

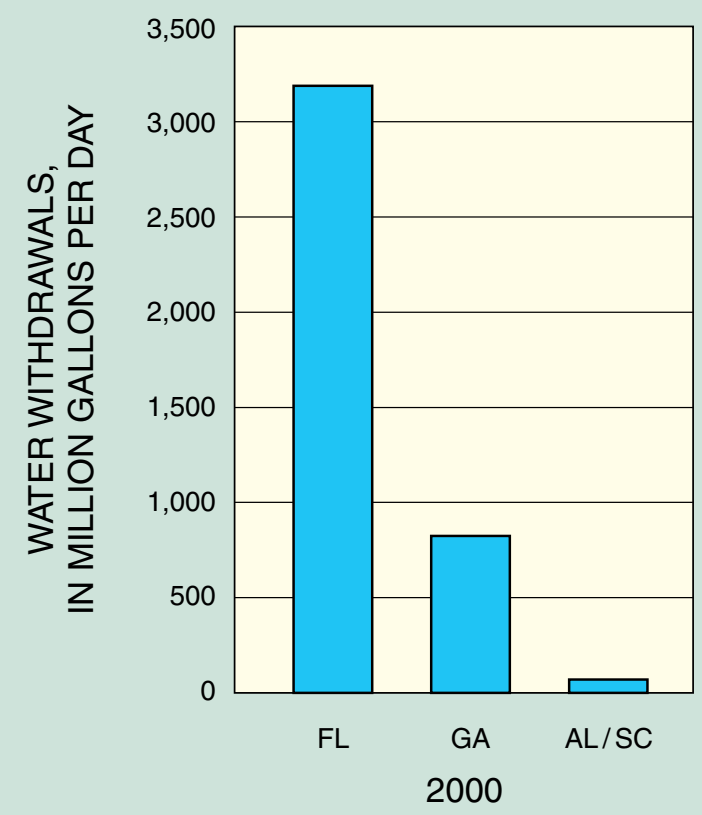

Figure 5. Water withdrawals from the Floridan aquifer system by state, 2000. (Fanning, 2003; Marella, 2004.) areas. Localized contamination of the Upper Floridan aquifer, however, has forced water suppliers to obtain water from the Lower Floridan aquifer. In central and northeastern Florida, water from the Lower Floridan is potable, but in most other areas the water does not meet national drinking water standards because of high chloride concentrations (Berndt and others, 1998b).

The Floridan aquifer system is the primary source of drinking water for most cities in central and northern Florida, including Daytona Beach, Gainesville, Jacksonville, Lakeland, Orlando, St. Petersburg, Tallahassee, and Tampa. The aquifer system also is the primary drinking water source for most cities in eastern and southern Georgia, including Brunswick, Savannah, and Valdosta. An estimated 8.2 million people obtained drinking water from public-water supplies derived from the Floridan aquifer system in 2000. Another 1.6 million people obtained their drinking water from domestic wells that tap this aquifer system.

Nine public-water suppliers each withdrew more than $20 \mathrm{Mgal} / \mathrm{d}$ of water from the Floridan aquifer system in 2000 (fig. 6). Tampa Bay Water, the

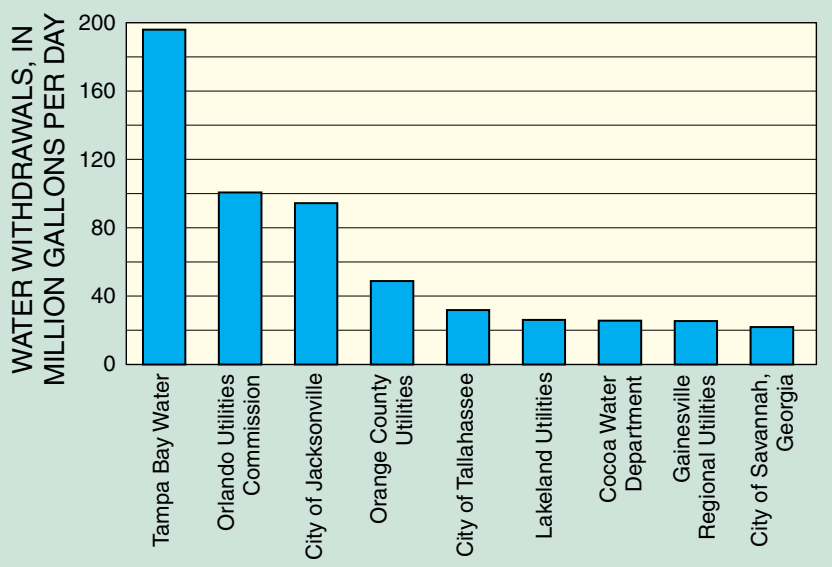

Figure 6. Water withdrawals from the Floridan aquifer system by the largest public-water suppliers, 2000. 
largest water supplier using the Floridan aquifer system in 2000, withdrew nearly $200 \mathrm{Mgal} / \mathrm{d}$ of ground water (plus $80 \mathrm{Mgal} / \mathrm{d}$ of surface water) to supply more than 1.7 million people in the Tampa Bay area (Southwest Florida Water Management District, 2002). Tampa Bay Water supplies the cities of Clearwater, St. Petersburg, and Tampa and many other public water systems in Hillsborough, Pasco, and Pinellas Counties, Florida. Other water suppliers withdrawing large amounts of water from the Floridan aquifer system include Orlando Utilities Commission in Orange County, Florida (100 Mgal/d), and Jacksonville Electric Authority (City of Jacksonville) in Duval County, Florida (95 Mgal/d) (St. Johns River Water Management District, 2004).

Irrigation (1,949 Mgal/d; 49 percent) and public supply (1,329 Mgal/d; 33 percent) were the two largest categories of withdrawal from the Floridan aquifer system and accounted for about 82 percent of the water withdrawn in 2000 (fig. 7). The irrigation category includes water used for agriculture crop irrigation, livestock, and golf course irrigation. Industrial (including commercial, mining and power generation) and domestic self-supplied withdrawals in 2000 were $576 \mathrm{Mgal} / \mathrm{d}$ (14 percent) and $166 \mathrm{Mgal} / \mathrm{d}$ (4 percent), respectively. Throughout most of Alabama, Florida, Georgia, and South Carolina, 2000 was an extremely dry year with drought conditions (University of Nebraska, 2004) resulting in higher-thannormal water demands for all irrigation purposes (agriculture crops, golf courses, and residential lawns).

Ten counties in Florida (Brevard, DeSoto, Duval, Highlands, Hillsborough, Manatee, Orange, Osceola, Pasco, and Polk) each withdrew more than $100 \mathrm{Mgal} / \mathrm{d}$ from the Floridan aquifer system (fig. 8), and accounted for more than 40 percent $(1,683 \mathrm{Mgal} / \mathrm{d})$ of the total water withdrawn in 2000. The largest withdrawals in 2000 were in Polk (318 Mgal/d) and Orange (280 Mgal/d) Counties, Florida (table 1). Figure 9 shows the Floridan aquifer system in the southeastern United States by county.

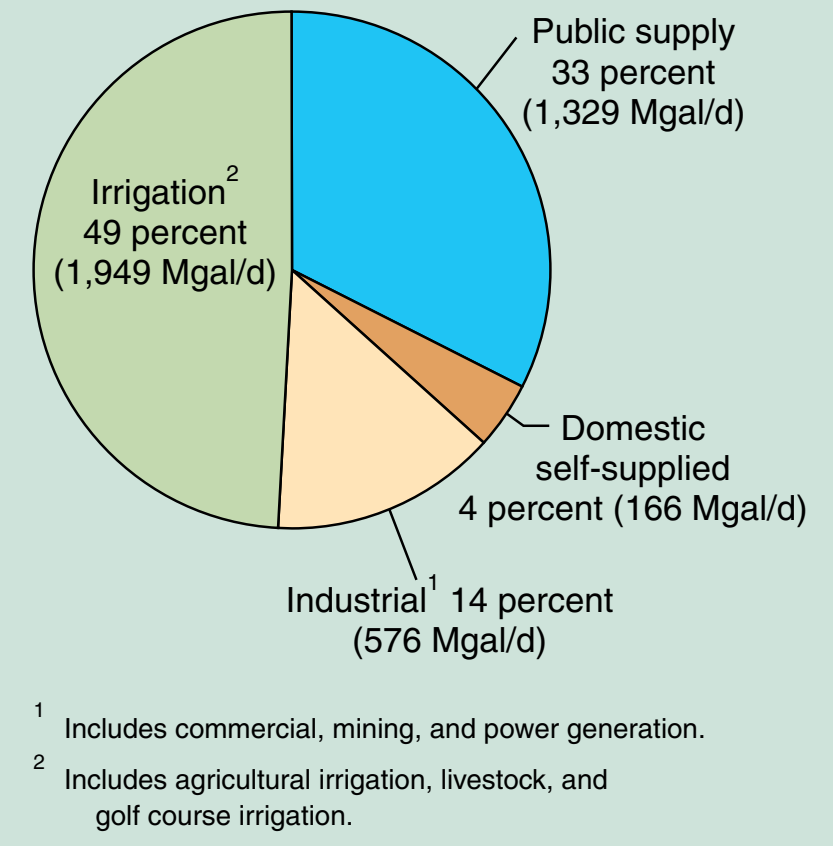

Figure 7. Water withdrawals from the Floridan aquifer system by category, 2000.

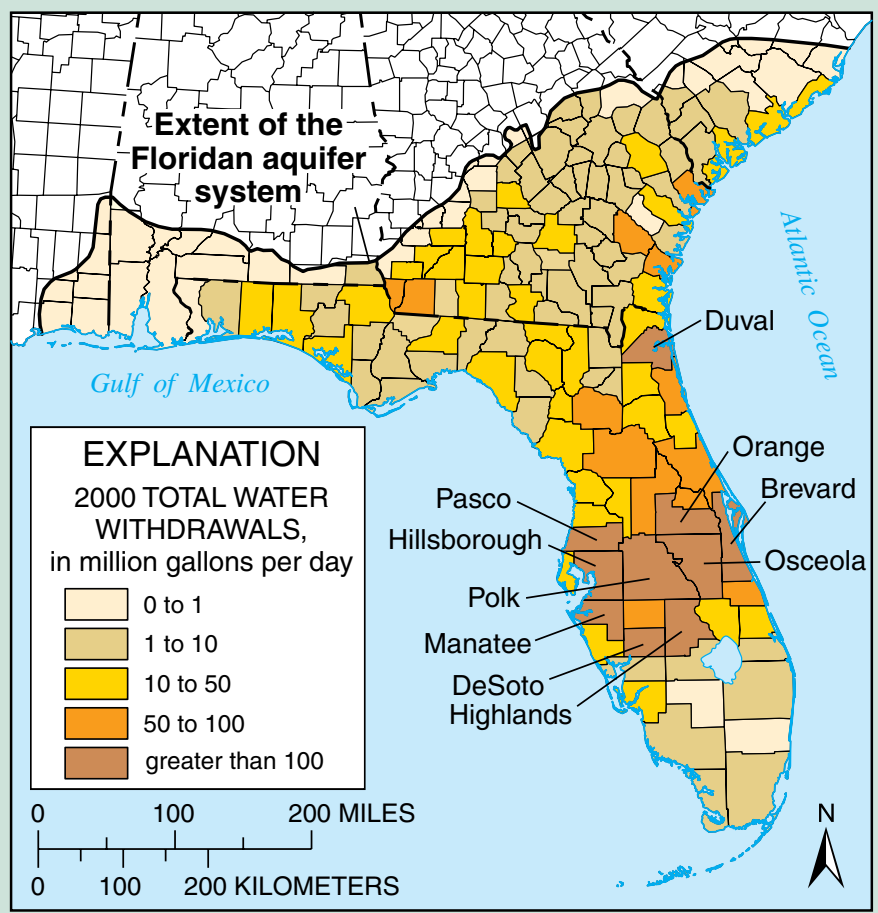

Figure 8. Water withdrawals from the Floridan aquifer system by county, 2000. (Fanning, 2003; Marella, 2004.) 
Table 1. Water withdrawals from the Floridan aquifer system by county, 2000.

[Compiled by the U.S. Geological Survey, Tallahassee. General county locations are shown on figure 9. No water was reported withdrawn from the Floridan aquifer system in Mississippi during 2000]

\begin{tabular}{|c|c|c|c|c|c|}
\hline \multirow[b]{2}{*}{ State and County } & \multicolumn{5}{|c|}{ Water withdrawals, in million gallons per day } \\
\hline & $\begin{array}{l}\text { Public } \\
\text { supply }\end{array}$ & $\begin{array}{c}\text { Domestic } \\
\text { self-supplied }\end{array}$ & Industrial' & Irrigation $^{2}$ & Totals \\
\hline \multicolumn{6}{|l|}{ Alabama } \\
\hline Baldwin & 0.00 & 0.00 & 0.00 & 0.00 & 0.00 \\
\hline Choctaw & 0.00 & 0.00 & 0.00 & 0.00 & 0.00 \\
\hline Clarke & 0.00 & 0.00 & 0.00 & 0.00 & 0.00 \\
\hline Conecuh & 0.05 & 0.00 & 0.00 & 0.00 & 0.05 \\
\hline Covington & 0.42 & 0.14 & 0.00 & 0.00 & 0.56 \\
\hline Escambia & 0.00 & 0.00 & 0.00 & 0.00 & 0.00 \\
\hline Geneva & 0.00 & 0.46 & 0.00 & 0.00 & 0.46 \\
\hline Houston & 0.31 & 0.95 & 0.00 & 4.91 & 6.17 \\
\hline Mobile & 0.00 & 0.00 & 0.00 & 0.00 & 0.00 \\
\hline Monroe & 0.00 & 0.00 & 0.00 & 0.00 & 0.00 \\
\hline Washington & 0.00 & 0.00 & 0.00 & 0.00 & 0.00 \\
\hline \multicolumn{6}{|l|}{ Florida } \\
\hline Alachua & 28.26 & 3.70 & 5.13 & 22.07 & 59.16 \\
\hline Baker & 0.88 & 1.70 & 0.43 & 2.94 & 5.95 \\
\hline Bay & 6.28 & 1.81 & 1.19 & 2.74 & 12.02 \\
\hline Bradford & 1.38 & 1.70 & 1.25 & 1.27 & 5.60 \\
\hline Brevard & 6.73 & 1.70 & 1.24 & 113.88 & 123.55 \\
\hline Broward & 0.09 & 0.00 & 0.00 & 0.00 & 0.09 \\
\hline Calhoun & 0.75 & 0.84 & 0.00 & 2.66 & 4.25 \\
\hline Charlotte & 0.00 & 0.00 & 0.07 & 7.25 & 7.32 \\
\hline Citrus & 13.97 & 6.50 & 2.35 & 6.53 & 29.35 \\
\hline Clay & 14.77 & 3.82 & 6.87 & 7.51 & 32.97 \\
\hline Collier & 2.84 & 0.00 & 0.00 & 1.53 & 4.37 \\
\hline Columbia & 3.67 & 3.37 & 0.34 & 6.13 & 13.51 \\
\hline DeSoto & 4.49 & 0.05 & 0.03 & 105.44 & 110.01 \\
\hline Dixie & 0.67 & 0.90 & 0.26 & 1.59 & 3.42 \\
\hline Duval & 119.12 & 1.12 & 20.84 & 8.92 & 150.00 \\
\hline Escambia & 0.00 & 0.00 & 0.00 & 0.00 & 0.00 \\
\hline Flagler & 2.31 & 0.56 & 0.20 & 17.51 & 20.58 \\
\hline Franklin & 1.92 & 0.17 & 0.00 & 0.14 & 2.23 \\
\hline Gadsden & 3.06 & 1.67 & 0.92 & 3.10 & 8.75 \\
\hline Gilchrist & 0.27 & 1.20 & 0.26 & 13.97 & 15.70 \\
\hline Glades & 0.55 & 0.00 & 0.14 & 6.96 & 7.65 \\
\hline Gulf & 0.96 & 0.30 & 0.90 & 0.41 & 2.57 \\
\hline Hamilton & 0.95 & 0.67 & 34.39 & 5.53 & 41.54 \\
\hline Hardee & 1.78 & 0.06 & 6.66 & 73.23 & 81.73 \\
\hline
\end{tabular}


Table 1. Water withdrawals from the Floridan aquifer system by county, 2000.--Continued

[Compiled by the U.S. Geological Survey, Tallahassee. General county locations are shown on figure 9. No water was reported withdrawn from the Floridan aquifer system in Mississippi during 2000]

\begin{tabular}{|c|c|c|c|c|c|}
\hline \multirow[b]{2}{*}{ State and County } & \multicolumn{5}{|c|}{ Water withdrawals, in million gallons per day } \\
\hline & $\begin{array}{l}\text { Public } \\
\text { supply }\end{array}$ & $\begin{array}{c}\text { Domestic } \\
\text { self-supplied }\end{array}$ & Industrial' ${ }^{1}$ & Irrigation $^{2}$ & Totals \\
\hline \multicolumn{6}{|l|}{ Florida } \\
\hline Hendry & 0.25 & 0.00 & 0.00 & 0.00 & 0.25 \\
\hline Hernando & 20.26 & 1.27 & 19.70 & 8.09 & 49.32 \\
\hline Highlands & 9.14 & 0.09 & 0.58 & 123.96 & 133.77 \\
\hline Hillsborough & 85.51 & 3.99 & 14.17 & 91.19 & 194.86 \\
\hline Holmes & 1.38 & 1.22 & 0.00 & 1.04 & 3.64 \\
\hline Indian River & 8.03 & 1.68 & 0.00 & 64.30 & 74.01 \\
\hline Jackson & 2.46 & 2.90 & 1.80 & 14.39 & 21.55 \\
\hline Jefferson & 0.72 & 0.76 & 0.20 & 6.63 & 8.31 \\
\hline Lafayette & 0.20 & 0.55 & 0.20 & 5.77 & 6.72 \\
\hline Lake & 39.92 & 3.86 & 10.44 & 36.21 & 90.43 \\
\hline Lee & 15.9 & 0.00 & 0.00 & 3.50 & 19.40 \\
\hline Leon & 35.7 & 3.86 & 2.86 & 2.51 & 44.93 \\
\hline Levy & 2.16 & 3.55 & 0.06 & 22.27 & 28.04 \\
\hline Liberty & 0.39 & 0.40 & 0.82 & 0.16 & 1.77 \\
\hline Madison & 1.65 & 1.11 & 0.15 & 6.03 & 8.94 \\
\hline Manatee & 13.87 & 0.02 & 0.38 & 103.98 & 118.25 \\
\hline Marion & 27.99 & 14.78 & 2.08 & 21.19 & 66.04 \\
\hline Martin & 2.82 & 0.00 & 1.05 & 1.92 & 5.79 \\
\hline Miami-Dade & 0.00 & 0.00 & 3.68 & 0.00 & 3.68 \\
\hline Monroe & 0.00 & 0.00 & 0.14 & 1.23 & 1.37 \\
\hline Nassau & 6.81 & 0.87 & 32.46 & 3.48 & 43.62 \\
\hline Okaloosa & 22.97 & 1.14 & 4.14 & 3.77 & 32.02 \\
\hline Okeechobee & 0.00 & 0.15 & 0.14 & 47.47 & 47.76 \\
\hline Orange & 211.76 & 7.94 & 24.97 & 35.81 & 280.48 \\
\hline Osceola & 30.00 & 4.15 & 0.87 & 79.63 & 114.65 \\
\hline Palm Beach & 6.34 & 0.00 & 0.11 & 0.00 & 6.45 \\
\hline Pasco & 102.67 & 4.05 & 4.86 & 27.66 & 139.24 \\
\hline Pinellas & 39.88 & 0.37 & 0.09 & 2.82 & 43.16 \\
\hline Polk & 75.43 & 9.36 & 74.05 & 158.91 & 317.75 \\
\hline Putnam & 3.20 & 4.49 & 19.83 & 12.33 & 39.85 \\
\hline St. Johns & 10.82 & 1.72 & 0.01 & 34.14 & 46.69 \\
\hline St. Lucie & 5.65 & 0.74 & 0.00 & 40.59 & 46.98 \\
\hline Santa Rosa & 3.73 & 0.20 & 0.00 & 5.10 & 9.03 \\
\hline Sarasota & 17.21 & 0.01 & 0.25 & 9.76 & 27.23 \\
\hline Seminole & 66.90 & 2.46 & 0.08 & 18.76 & 88.20 \\
\hline
\end{tabular}


Table 1. Water withdrawals from the Floridan aquifer system by county, 2000.--Continued

[Compiled by the U.S. Geological Survey, Tallahassee. General county locations are shown on figure 9. No water was reported withdrawn from the Floridan aquifer system in Mississippi during 2000]

\begin{tabular}{|c|c|c|c|c|c|}
\hline \multirow[b]{2}{*}{ State and County } & \multicolumn{5}{|c|}{ Water withdrawals, in million gallons per day } \\
\hline & $\begin{array}{l}\text { Public } \\
\text { supply } \\
\end{array}$ & $\begin{array}{r}\text { Domestric } \\
\text { self-supplied }\end{array}$ & Industrial' $^{1}$ & Irrigation $^{2}$ & Totals \\
\hline \multicolumn{6}{|l|}{ Florida } \\
\hline Sumter & 4.44 & 4.11 & 0.36 & 17.43 & 26.34 \\
\hline Suwannee & 1.40 & 2.43 & 1.60 & 20.71 & 26.14 \\
\hline Taylor & 1.73 & 0.86 & 42.15 & 1.96 & 46.70 \\
\hline Union & 0.36 & 0.99 & 0.40 & 1.05 & 2.80 \\
\hline Volusia & 54.90 & 2.72 & 1.03 & 38.07 & 96.72 \\
\hline Wakulla & 2.19 & 1.44 & 0.68 & 0.48 & 4.79 \\
\hline Walton & 7.35 & 0.15 & 0.92 & 2.07 & 10.49 \\
\hline Washington & 1.16 & 1.28 & 0.22 & 1.52 & 4.18 \\
\hline \multicolumn{6}{|l|}{ Georgia } \\
\hline Appling & 1.05 & 0.82 & 0.17 & 2.44 & 4.48 \\
\hline Atkinson & 0.42 & 0.26 & 0.16 & 2.34 & 3.18 \\
\hline Bacon & 0.49 & 0.47 & 0.28 & 3.17 & 4.41 \\
\hline Baker & 0.25 & 0.24 & 0.00 & 38.31 & 38.80 \\
\hline Ben Hill & 4.21 & 0.55 & 0.00 & 3.60 & 8.36 \\
\hline Berrien & 0.80 & 0.60 & 0.18 & 6.93 & 8.51 \\
\hline Bleckley & 0.37 & 0.17 & 0.01 & 2.16 & 2.71 \\
\hline Brantley & 0.39 & 0.95 & 0.00 & 0.18 & 1.52 \\
\hline Brooks & 1.61 & 0.65 & 0.00 & 2.67 & 4.93 \\
\hline Bryan & 1.56 & 0.63 & 0.00 & 0.05 & 2.24 \\
\hline Bulloch & 3.41 & 1.24 & 1.33 & 6.49 & 12.47 \\
\hline Burke & 0.00 & 0.00 & 0.78 & 0.00 & 0.78 \\
\hline Calhoun & 0.00 & 0.00 & 0.00 & 0.00 & 0.00 \\
\hline Camden & 3.75 & 0.99 & 37.21 & 0.66 & 42.61 \\
\hline Candler & 0.66 & 0.40 & 0.00 & 2.23 & 3.29 \\
\hline Charlton & 0.71 & 0.55 & 0.00 & 0.12 & 1.38 \\
\hline Chatham & 33.45 & 2.23 & 31.50 & 5.81 & 72.99 \\
\hline Clinch & 0.53 & 0.25 & 0.00 & 0.73 & 1.51 \\
\hline Coffee & 5.44 & 1.36 & 0.00 & 5.45 & 12.25 \\
\hline Colquitt & 4.45 & 1.58 & 0.53 & 11.27 & 17.83 \\
\hline Cook & 2.15 & 0.51 & 0.00 & 5.19 & 7.85 \\
\hline Crisp & 0.18 & 0.42 & 0.00 & 4.40 & 5.00 \\
\hline Decatur & 2.65 & 1.11 & 0.92 & 50.52 & 55.20 \\
\hline Dodge & 1.11 & 0.77 & 0.06 & 1.00 & 2.94 \\
\hline Dooly & 0.00 & 0.00 & 0.00 & 0.00 & 0.00 \\
\hline Dougherty & 0.06 & 0.00 & 8.17 & 5.08 & 13.31 \\
\hline Early & 0.00 & 0.00 & 0.00 & 0.00 & 0.00 \\
\hline
\end{tabular}


Table 1. Water withdrawals from the Floridan aquifer system by county, 2000.--Continued

[Compiled by the U.S. Geological Survey, Tallahassee. General county locations are shown on figure 9. No water was reported withdrawn from the Floridan aquifer system in Mississippi during 2000]

\begin{tabular}{|c|c|c|c|c|c|}
\hline \multirow[b]{2}{*}{ State and County } & \multicolumn{5}{|c|}{ Water withdrawals, in million gallons per day } \\
\hline & $\begin{array}{l}\text { Public } \\
\text { supply }\end{array}$ & $\begin{array}{c}\text { Domestic } \\
\text { self-supplied }\end{array}$ & 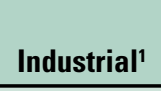 & Irrigation $^{2}$ & Totals \\
\hline \multicolumn{6}{|l|}{ Georgia } \\
\hline Echols & 0.06 & 0.25 & 0.00 & 5.76 & 6.07 \\
\hline Effingham & 1.91 & 0.96 & 2.19 & 0.23 & 5.29 \\
\hline Emanuel & 1.50 & 0.36 & 0.00 & 1.27 & 3.13 \\
\hline Evans & 0.59 & 0.10 & 1.50 & 1.04 & 3.23 \\
\hline Glynn & 12.42 & 0.65 & 49.80 & 0.00 & 62.87 \\
\hline Grady & 1.98 & 0.83 & 0.00 & 6.25 & 9.06 \\
\hline Houston & 0.00 & 0.00 & 0.00 & 0.00 & 0.00 \\
\hline Irwin & 0.76 & 0.45 & 0.00 & 6.33 & 7.54 \\
\hline Jeff Davis & 0.83 & 0.48 & 0.35 & 2.81 & 4.47 \\
\hline Jefferson & 0.39 & 0.00 & 0.00 & 2.36 & 2.75 \\
\hline Jenkins & 0.27 & 0.17 & 0.01 & 1.98 & 2.43 \\
\hline Johnson & 0.18 & 0.21 & 0.00 & 0.81 & 1.20 \\
\hline Lanier & 0.56 & 0.33 & 0.00 & 1.41 & 2.30 \\
\hline Laurens & 0.27 & 0.51 & 0.00 & 2.15 & 2.93 \\
\hline Lee & 0.00 & 0.00 & 0.00 & 0.00 & 0.00 \\
\hline Liberty & 6.28 & 0.86 & 10.00 & 0.09 & 17.23 \\
\hline Long & 0.27 & 0.48 & 0.00 & 0.09 & 0.84 \\
\hline Lowndes & 9.30 & 2.00 & 10.89 & 7.42 & 29.61 \\
\hline Macon & 0.00 & 0.00 & 0.00 & 0.00 & 0.00 \\
\hline McIntosh & 0.87 & 0.15 & 0.03 & 0.01 & 1.06 \\
\hline Miller & 0.30 & 0.30 & 0.00 & 30.25 & 30.85 \\
\hline Mitchell & 2.58 & 0.42 & 0.00 & 29.00 & 32.00 \\
\hline Montgomery & 0.48 & 0.21 & 0.00 & 1.12 & 1.81 \\
\hline Pierce & 0.69 & 0.80 & 0.00 & 6.03 & 7.52 \\
\hline Pulaski & 0.10 & 0.13 & 0.76 & 3.96 & 4.95 \\
\hline Randolph & 0.00 & 0.00 & 0.00 & 0.00 & 0.00 \\
\hline Screven & 0.63 & 0.37 & 0.91 & 7.82 & 9.73 \\
\hline Seminole & 0.65 & 0.40 & 0.00 & 62.67 & 63.72 \\
\hline Sumter & 0.00 & 0.00 & 0.00 & 0.00 & 0.00 \\
\hline Tattnall & 1.18 & 0.97 & 1.17 & 3.37 & 6.69 \\
\hline Telfair & 1.88 & 0.19 & 0.10 & 2.66 & 4.83 \\
\hline Terrell & 0.00 & 0.00 & 0.00 & 0.00 & 0.00 \\
\hline Thomas & 7.13 & 0.81 & 0.38 & 8.88 & 17.20 \\
\hline Tift & 6.58 & 0.78 & 0.13 & 9.50 & 16.99 \\
\hline Toombs & 2.66 & 0.42 & 0.00 & 3.89 & 6.97 \\
\hline
\end{tabular}


Table 1. Water withdrawals from the Floridan aquifer system by county, 2000.--Continued

[Compiled by the U.S. Geological Survey, Tallahassee. General county locations are shown on figure 9. No water was reported withdrawn from the Floridan aquifer system in Mississippi during 2000]

\begin{tabular}{|c|c|c|c|c|c|}
\hline \multirow[b]{2}{*}{ State and County } & \multicolumn{5}{|c|}{ Water withdrawals, in million gallons per day } \\
\hline & $\begin{array}{l}\text { Public } \\
\text { supply }\end{array}$ & $\begin{array}{l}\text { Domestric self- } \\
\text { supplied }\end{array}$ & Industrial' ${ }^{1}$ & Irrigation $^{2}$ & Totals \\
\hline \multicolumn{6}{|l|}{ Georgia } \\
\hline Treutlen & 0.45 & 0.29 & 0.00 & 0.51 & 1.25 \\
\hline Turner & 0.71 & 0.24 & 0.00 & 6.03 & 6.98 \\
\hline Twiggs & 0.00 & 0.00 & 0.00 & 0.00 & 0.00 \\
\hline Ware & 3.85 & 0.41 & 1.61 & 2.98 & 8.85 \\
\hline Washington & 0.47 & 0.25 & 0.00 & 1.74 & 2.46 \\
\hline Wayne & 1.91 & 1.09 & 59.52 & 1.46 & 63.98 \\
\hline Wheeler & 0.27 & 0.30 & 0.00 & 0.69 & 1.26 \\
\hline Wilcox & 0.62 & 0.33 & 0.00 & 17.20 & 18.15 \\
\hline Worth & 1.46 & 0.92 & 0.00 & 25.37 & 27.75 \\
\hline \multicolumn{6}{|l|}{ South Carolina } \\
\hline Allendale & 1.20 & 0.27 & 2.50 & 5.62 & 9.59 \\
\hline Bamberg & 0.00 & 0.00 & 0.00 & 0.00 & 0.00 \\
\hline Barnwell & 0.00 & 0.00 & 0.00 & 0.00 & 0.00 \\
\hline Beaufort & 11.79 & 0.52 & 0.89 & 11.40 & 24.60 \\
\hline Berkley & 0.00 & 0.00 & 0.00 & 0.20 & 0.20 \\
\hline Calhoun & 0.00 & 0.00 & 0.00 & 0.00 & 0.00 \\
\hline Charleston & 6.13 & 2.56 & 0.27 & 2.20 & 11.16 \\
\hline Clarendon & 0.00 & 0.00 & 0.00 & 0.00 & 0.00 \\
\hline Colleton & 2.35 & 1.30 & 0.13 & 0.72 & 4.50 \\
\hline Dorchester & 0.00 & 0.00 & 0.00 & 0.00 & 0.00 \\
\hline Georgetown & 0.00 & 0.00 & 0.00 & 0.00 & 0.00 \\
\hline Hampton & 1.80 & 0.47 & 0.69 & 5.67 & 8.63 \\
\hline Jasper & 1.26 & 0.18 & 0.15 & 2.87 & 4.46 \\
\hline Orangeburg & 0.00 & 0.00 & 0.00 & 0.00 & 0.00 \\
\hline Williamsburg & 0.00 & 0.00 & 0.00 & 0.00 & 0.00 \\
\hline TOTALS & 1,329.00 & 165.53 & 576.28 & $1,948.73$ & $4,019.54$ \\
\hline
\end{tabular}

${ }^{1}$ Industrial includes commercial, mining, and power generation.

${ }^{2}$ Irrigation includes agricultural irrigation and non-irrigation (livestock) and golf course irrigation. 


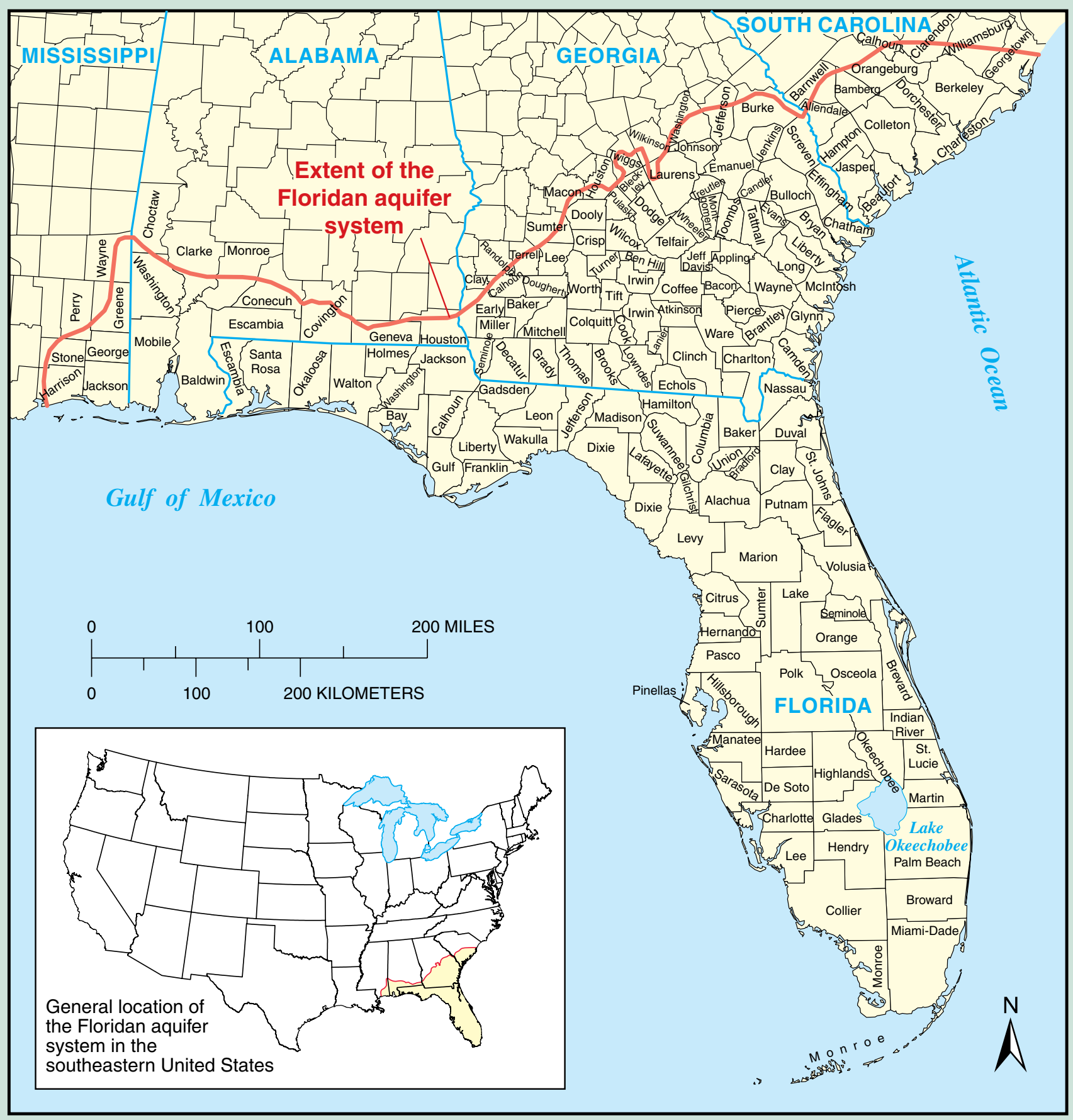

Figure 9. Extent of the Floridan aquifer system in the southeastern United States by county. 


\section{Water Withdrawal Trends, 1950-2000}

Withdrawals of water from the Floridan aquifer system have increased by more than 500 percent from $630 \mathrm{Mgal} / \mathrm{d}$ in 1950 (Bush and Johnston, 1988) to 4,020 Mgal/d in 2000 (fig. 10). The increase in withdrawals is attributed to increases in population, tourism, and agriculture production throughout the southeastern United States. Between 1950 and 2000, the combined populations of Alabama, Florida, Georgia, and South Carolina increased by more than 19 million people or 169 percent (Hobbs and Stoops, 2002). A slight decrease in withdrawals from 1990-1995 is attributed to aboveaverage rainfall across the Southeast in 1995, which resulted in lower water demands for all irrigation purposes (agriculture crops, golf courses, and residential lawns).

Withdrawals from the Floridan aquifer system increased from 1950 to 2000 in each of the major withdrawal categories (public supply, irrigation, and industrial) (fig. 11). Public-supply withdrawals increased from $85 \mathrm{Mgal} / \mathrm{d}$ in 1950 (Bush and Johnston, 1988) to $1,329 \mathrm{Mgal} / \mathrm{d}$ in 2000; nearly 60 percent of the increase occurred during the 20-year period between 1980-2000 (table 2). Population served by public supply increased from 4.5 million in 1980 to 8.2 million in 2000. Domestic self-supplied withdrawals increased from $45 \mathrm{Mgal} / \mathrm{d}$ in 1950 (Bush and Johnston, 1988) to $166 \mathrm{Mgal} / \mathrm{d}$ in 2000 (table 2).

Irrigation withdrawals increased from $90 \mathrm{Mgal} / \mathrm{d}$ in 1950 (Bush and Johnston, 1988) to $1,949 \mathrm{Mgal} / \mathrm{d}$ in 2000 (table 2, fig. 11). Between 1960 and 2000, irrigated agricultural acreage in Alabama, Florida, Georgia, and South Carolina increased by more than 3 million acres (MacKichan and Kammerer, 1961; Hutson and others, 2004). More than 60 percent of this increase occurred during the 20-year period between 1970-1990, when irrigation systems were introduced into north Florida and southwest Georgia (Pierce and others, 1984; Solley and others, 1998). Irrigation withdrawals decreased slightly

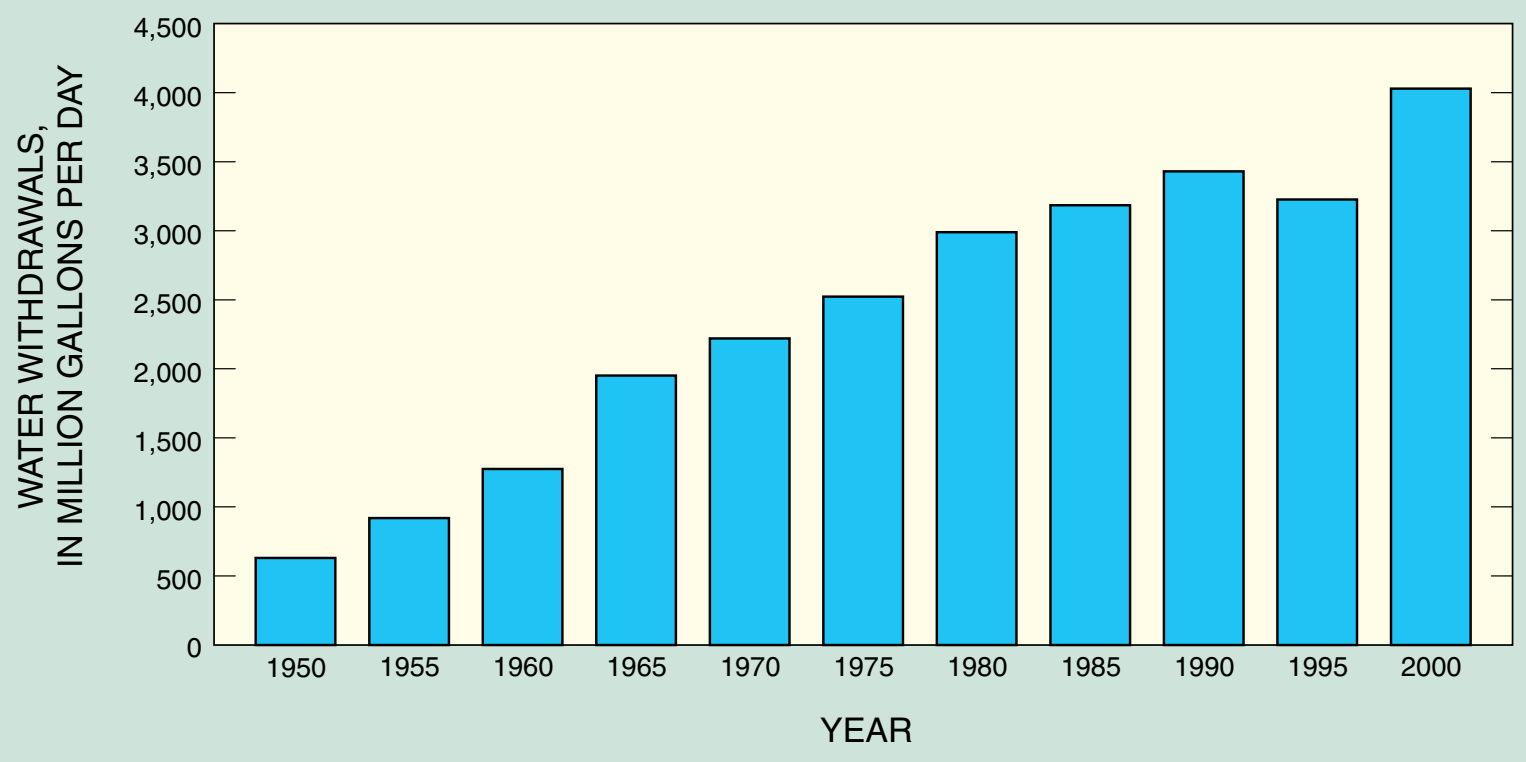

Figure 10. Total water withdrawals from the Floridan aquifer system, 1950-2000. (1950-1980 data from Bush and Johnston, 1988; 1985 data from Carr and others, 1990; 1990-1995 data from U.S. Geological Survey unpublished wateruse data.) 
from 1990-1995 due to above-average rainfall during 1995, and increased from 1995-2000 because of belowaverage rainfall across the Southeast during that period.

Industrial water withdrawals increased from $410 \mathrm{Mgal} / \mathrm{d}$ in 1950 (Bush and Johnston, 1988) to $1,103 \mathrm{Mgal} / \mathrm{d}$ in 1975 , but decreased to $576 \mathrm{Mgal} / \mathrm{d}$ in 2000 (table 2, fig. 11). Lower industrial withdrawals after the mid-1970s are a result of improved efficiencies, increased water recycling and conservation measures, and changes in regulations designed to reduce the discharge of pollutants (Solley and others, 1998). A large portion of the recent decrease between 1990 and 2000 is a result of several large self-supplied industrial facilities closing in Florida and Georgia.

Ground water from the Floridan aquifer system is the primary source of irrigation water in central and north Florida and south Georgia.

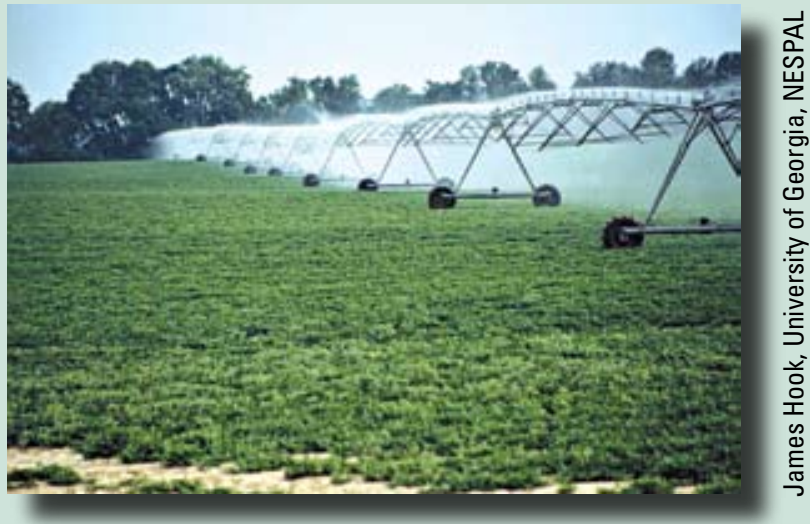

Center pivot used to irrigate peanuts in southwest Georgia.

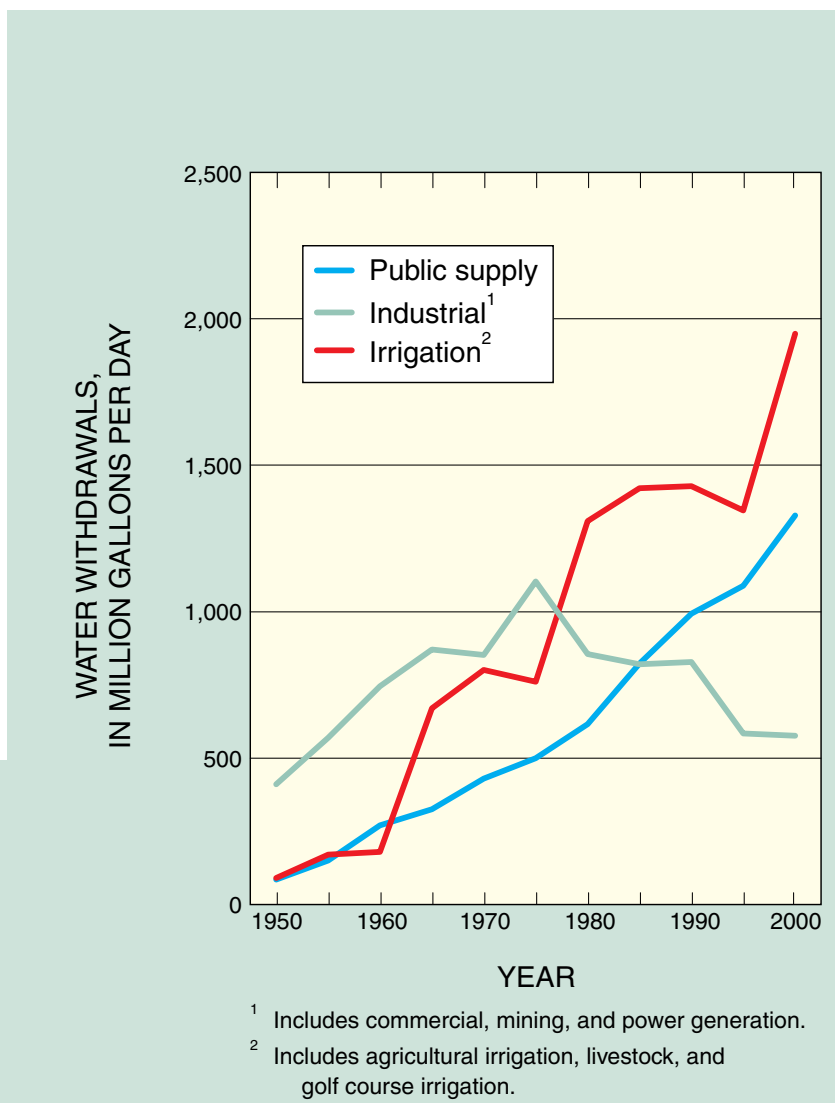

Figure 11. Water withdrawals from the Floridan aquifer system by category, 1950-2000. (Bush and Johnston, 1988; Carr and others, 1990; U.S. Geological Survey unpublished water-use data.)

Table 2. Water withdrawals from the Floridan aquifer system by category, 1950-2000.

[Withdrawals in million gallons per day. Sources: 1950-1980 data from Bush and Johnston, 1988; 1985 data from Carr and others, 1990; 1990-1995 data from U.S. Geological Survey unpublished water-use data]

\begin{tabular}{lrrrrrrrrrrrr}
\hline \multicolumn{1}{c}{ Category } & $\mathbf{1 9 5 0}$ & $\mathbf{1 9 5 5}$ & $\mathbf{1 9 6 0}$ & $\mathbf{1 9 6 5}$ & $\mathbf{1 9 7 0}$ & $\mathbf{1 9 7 5}$ & $\mathbf{1 9 8 0}$ & $\mathbf{1 9 8 5}$ & $\mathbf{1 9 9 0}$ & $\mathbf{1 9 9 5}$ & $\mathbf{2 0 0 0}$ \\
\hline Public supply & 85 & 150 & 270 & 325 & 430 & 500 & 616 & 822 & 993 & 1,088 & 1,329 \\
Domestic self-supplied & 45 & 30 & 80 & 87 & 138 & 158 & 209 & 120 & 181 & 209 & 166 \\
Industrial $^{1}$ & 410 & 570 & 745 & 870 & 852 & 1,103 & 855 & 820 & 828 & 584 & 576 \\
Irrigation $^{2}$ & 90 & 170 & 180 & 670 & 801 & 761 & 1,310 & 1,422 & 1,428 & 1,345 & 1,949 \\
\multicolumn{1}{c}{ Totals } & $\mathbf{6 3 0}$ & $\mathbf{9 2 0}$ & $\mathbf{1 , 2 7 5}$ & $\mathbf{1 , 9 5 2}$ & $\mathbf{2 , 2 2 1}$ & $\mathbf{2 , 5 2 2}$ & $\mathbf{2 , 9 9 0}$ & $\mathbf{3 , 1 8 4}$ & $\mathbf{3 , 4 3 0}$ & $\mathbf{3 , 2 2 6}$ & $\mathbf{4 , 0 2 0}$ \\
\hline
\end{tabular}

${ }^{1}$ Includes commercial, mining, and power generation.

${ }^{2}$ Includes agricultural irrigation, livestock, and golf course irrigation. 


\section{Water Quantity and Quality Concerns}

The cumulative effects of large quantities of groundwater withdrawals from the Floridan aquifer system have caused extensive water-level drawdowns and saltwater intrusion in many areas. In northeastern Florida and eastern Georgia (near Savannah, Georgia), water levels have declined since 1950 at an average rate of about onethird to one-half foot per year (Barlow, 2003) (fig. 12). Along coastal areas of the western panhandle of Florida (near Pensacola, Florida), water levels have declined about 100 feet since 1950 (fig. 12); consequently, well fields have been relocated farther inland or have been supplemented with surface water (Purdum and Penson, 1998). Effects of increased water withdrawals also are evident at many lakes, wetlands, and springs, as lake levels have declined and wetlands have dried up in many areas throughout Florida (Kautz and others, 1998) and discharge at some springs has decreased or ceased over time (Spechler and Schiffer, 1995).

Along the coasts of Georgia and South Carolina, high chloride concentrations in ground water in the aquifer system are attributed to intrusion of seawater caused by large ground-water withdrawals in the Savannah, Georgia, and Hilton Head Island, South Carolina, areas (Barlow, 2003). Other areas that have limited withdrawals because of elevated chloride concentrations or the potential for saltwater intrusion include the central east and west coasts of Florida (Berndt and others, 1998b; Barlow, 2003) and along the coast of Georgia (Krause and Clarke, 2001).

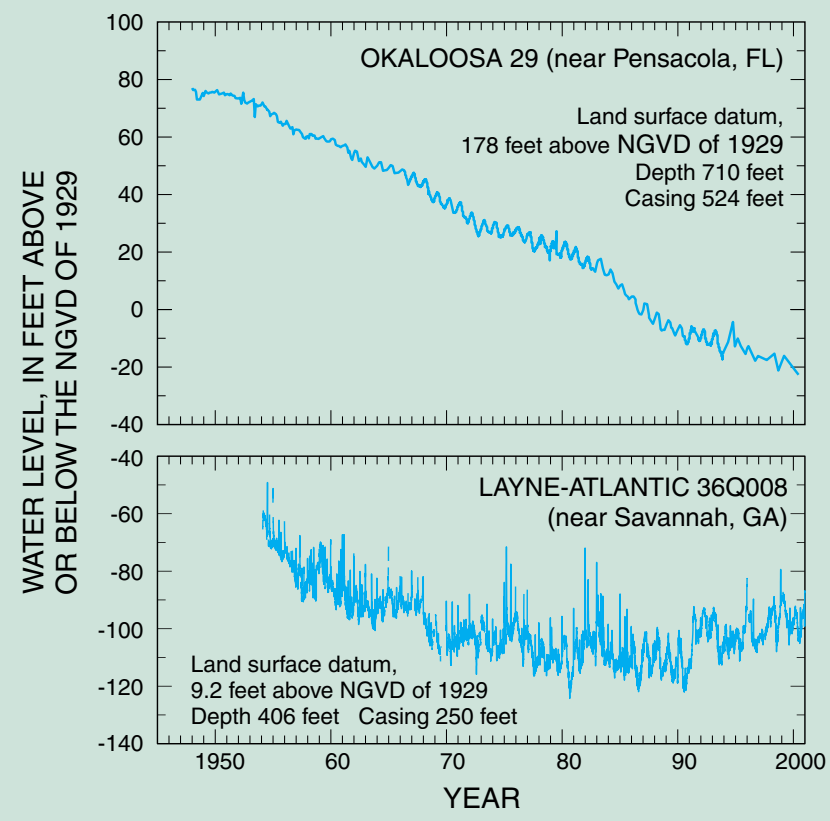

Figure 12. Fluctuations of ground-water levels in selected wells in the Upper Floridan aquifer. (Marella and Sepúlveda, 2004; Michael Peck, U.S. Geological Survey, written commun., April 2004.)
Sinkholes provide a direct pathway for contaminants to enter the aquifer.

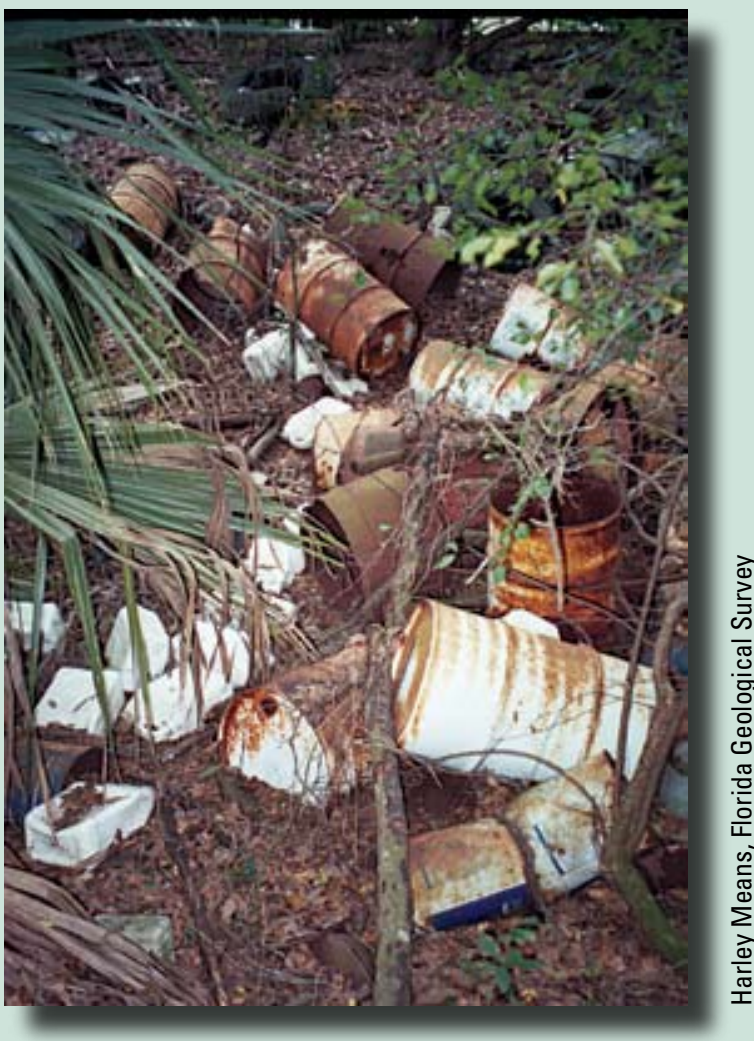

Empty pesticide cans litter a sinkhole in central Florida. 
Increased water withdrawals from the Floridan aquifer system have resulted in lower lake levels throughout central, north, and southwest Florida.

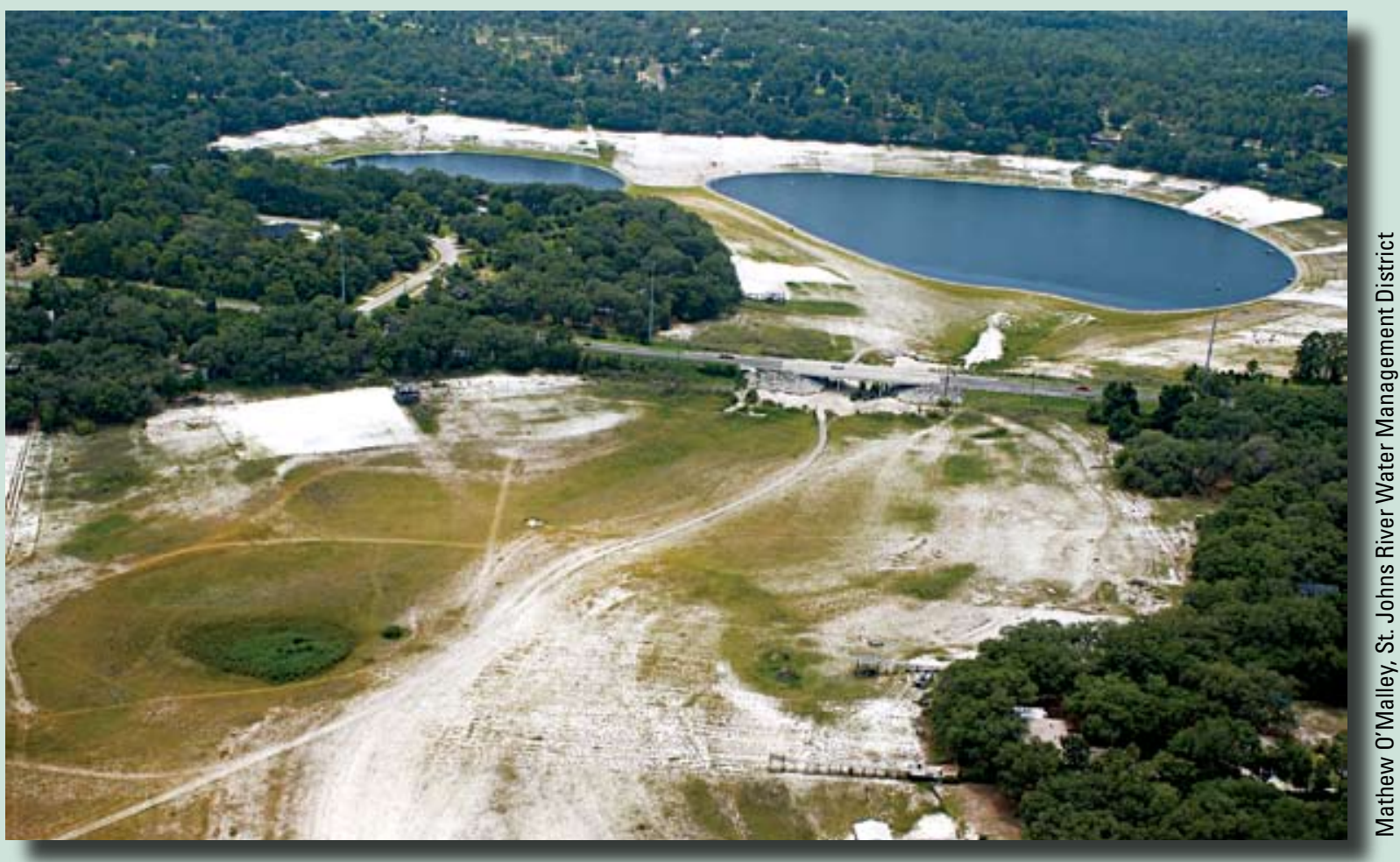

Lowered lake levels in northern Florida are evident by docks and bridges that rise from dried lake bottoms.

Land-use practices affect the water quality of the Floridan aquifer system. The aquifer system is unconfined in many areas and sinkholes and sinking streams commonly provide a direct pathway for land-surface contaminants to enter the ground-water system. Nitrate, herbicides, and pesticides from agricultural activities have been detected in many of the springs and wells in northern Florida. For example, nitrate concentrations in Manatee Springs (near Gainesville, Florida) have increased from 0.4 milligrams per liter in 1946 to more than 1.5 milligrams per liter in the late 1990s (Katz and others, 1999). Herbicides also have been detected in trace concentrations in 9 of 15 springs discharging from the Upper Floridan aquifer in south Georgia (Hippe, 1997). In addition, household trash and other waste products have been dumped in sinkholes throughout the years, thus providing a direct source of contamination to the aquifer.

Urban runoff and septic tank effluent can affect the quality of water in populated areas by contributing nitrate and organic compounds (Bradner, 1991; Berndt and others, 1998a; Christy Crandall, U.S. Geological Survey, written commun., 2004). In the Orlando area (Orange County, Florida), 240 drainage wells allow

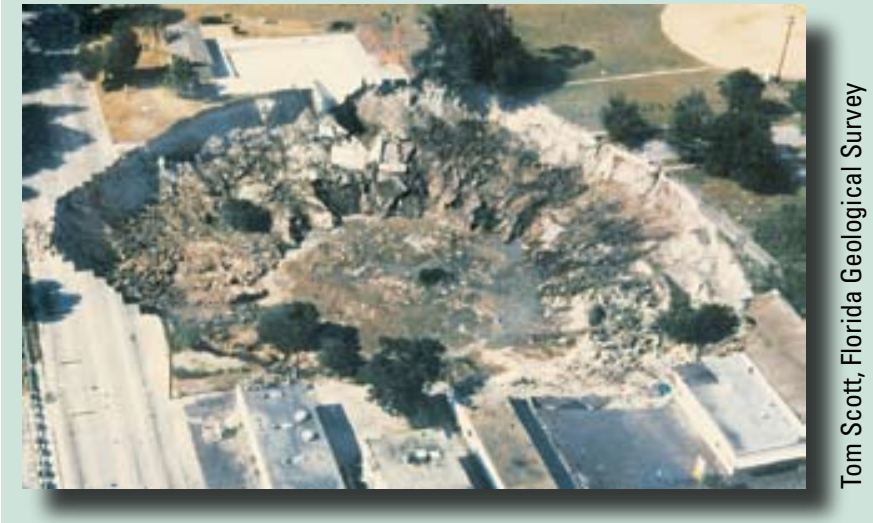

Aerial photograph of a large sinkhole that formed in Winter Park, Florida, May 1981. Sinkholes are a common feature of the Floridan aquifer system in central and north Florida.

untreated stormwater and urban runoff to directly enter the Upper Floridan aquifer (Sepúlveda, 2002). As a result, several water-supply systems in this area can no longer depend entirely on the Upper Floridan aquifer for drinking water, and now must also rely on the deeper Lower Floridan aquifer. About 40 percent of the water withdrawn in Orange County for public supply was obtained from the Lower Floridan aquifer in 2000 (McGurk and Presley, 2002). 
Most urban areas throughout central, north, and southwest Florida depend on water from the Floridan aquifer systems as their primary souce of water.

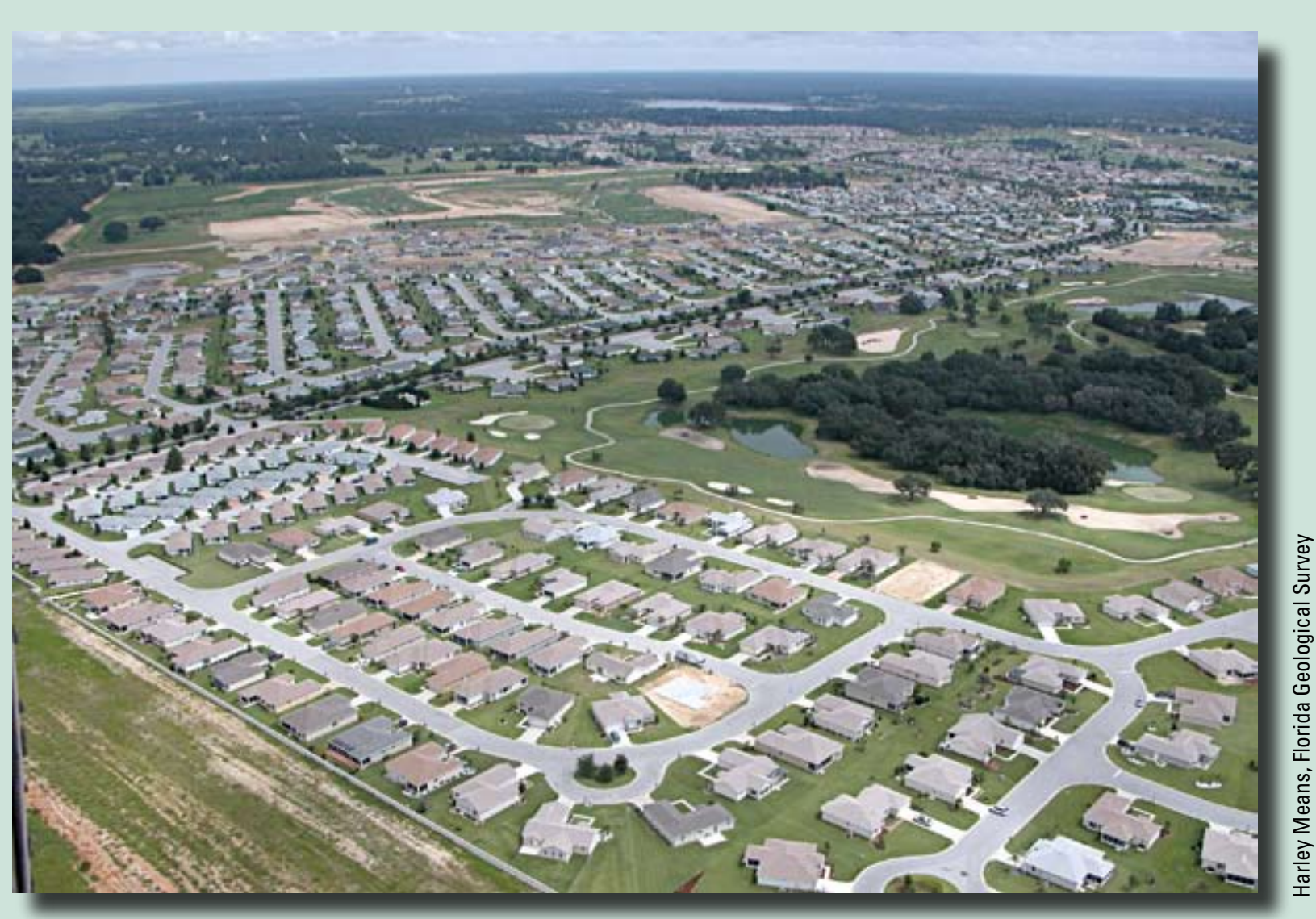

Large housing developments, like this one in southwest Florida, have resulted in a large increase in public-supply water demands over the past 30 years. 


\section{References}

Aucott, W.R., Davis, M.E., and Speiran, G.K., 1986, Geohydrologic framework for the Coastal Plain aquifers of South Carolina: U.S. Geological Survey WaterResources Investigations Report 85-4271, 7 sheets.

Barlow, P.M., 2003, Ground water in freshwater-saltwater environments of the Atlantic Coast: U.S. Geological Survey Circular 1262, 113 p.

Berndt, M.P., Galeone, D.R., Spruill, T.B., and Crandall, C.A., 1998a, Ground-water quality in three urban areas in the Coastal Plain of the southeastern United States, 1995: U.S. Geological Survey Water-Resources Investigations Report 97-4234, 25 p.

Berndt, M.P., Oaksford, E.T., and Mahon G.L., 1998b, Groundwater, in Fernald, E.A., and Purdum, E.D., Water resources atlas of Florida: Florida State University, Institute of Science and Public Affairs, p. 38-63.

Bradner, L.A., 1991, Water quality in the upper Floridan aquifer in the vicinity of drainage wells, Orlando, Florida: U.S. Geological Survey Water-Resources Investigations Report 90-4175, 57 p.

Bush, P.W., and Johnston, R.H., 1988, Ground-water hydraulics, regional flow, and ground-water development of the Floridan aquifer system in Florida and parts of Georgia, South Carolina, and Alabama: U.S. Geological Survey Professional Paper 1403-C, 80 p.

Carr, J.E., Chase, E.B., Paulson, R.W., and Moody, D.W., 1990, National water summary 1987-Hydrologic events and water supply and use: U.S. Geological Survey Water-Supply Paper 2350, 553 p.

Fanning, J.L., 2003, Water use in Georgia by county for 2000 and water-use trends for 1980-2000: Atlanta, Georgia Department of Natural Resources, Environmental Protection Division, Georgia Geologic Survey Information Circular 106, 176 p.
Gilliom, R.J., Hamilton, P.A., and Miller, T.L., 2001, The National Water-Quality Assessment ProgramEntering a new decade of investigations: U.S. Geological Survey Fact Sheet 071-01, 4 p.

Hobbs, Frank, and Stoops, Nicole, 2002, Demographic trends in the 20th century: Washington D.C., U.S. Department of Commerce, Census Bureau, Census 2000 Special Reports, Series CENSR-4, 143 p.

Hippe, D.J., 1997, Pesticide occurrence in the Upper Floridan aquifer in the Dougherty Plain and Marianna Lowlands districts, southwest Georgia and adjacent areas of Alabama and Florida, in Hatcher, K.J. ed., Proceedings of the 1997 Georgia Water Resource Conference, University of Georgia, Athens, Georgia, p. 65-67.

Hutson, S.S., Barber, N.L., Kenny, J.F., Linsey, K.S., Lumia, D.S., and Maupin, M.A., 2004, Estimated use of water in the United States in 2000: U.S. Geological Survey Circular 1268, 46 p.

Katz, B.G., Hornsby, H.D., Bohlke, J.F., and Mokray, M.F., 1999, Sources and chronology of nitrate contamination in spring waters, Suwannee River Basin, Florida: U.S. Geological Survey Water-Resources Investigations Report 99-4252, 54 p.

Kautz, R.S., Haddad, Kenneth, Hoehn, T.S., Rogers, Thomas, Estevez, E.D., and Atkeson, Tom, 1998, Natural systems, in Fernald, E.A., and Purdum, E.D., Water resources atlas of Florida: Florida State University, Institute of Science and Public Affairs, p. 82-113.

Krause, R.E., and Clarke, J.S., 2001, Coastal ground water at risk-Saltwater contamination at Brunswick, Georgia and Hilton Head Island, South Carolina: U.S. Geological Survey Water-Resources Investigations Report 01-4107, poster. 
MacKichan, K.A., and Kammerer, J.C., 1961, Estimated use of water in the United States, 1960: U.S. Geological Survey Circular 456, 44 p.

Marella, R.L., 2004, Water withdrawals, use, discharge, and trends in Florida, 2000, U.S. Geological Survey Scientific Investigations Report 2004-5151, 138 p.

Marella, R.L., and Sepúlveda, A.A., 2004, Potentiometric surface of the Upper Floridan aquifer in Florida, May 2000: Florida Geological Survey Map Series 149, 1 sheet.

Maupin, M.A., and Barber, N.L., 2005, Estimatd withdrawals from principal aquifers in the United States, 2000: U.S. Geological Survey Circular 1279, 46 p.

McGurk, Brian, and Presley, P.F., 2002, Simulation of the effects of groundwater withdrawals on the Floridan aquifer system in east-central Florida (Model expansion and revision): Palatka, St. Johns River Water Management District, Technical Publication SJ2002-3, $151 \mathrm{p}$.

Miller, J.A., 1986, Hydrogeologic framework of the Floridan aquifer system in Florida and in parts of Georgia, Alabama, and South Carolina: U.S. Geological Survey Professional Paper 1403-B, 91 p.

Miller, J.A., 1990, Ground water atlas of the United States, Segment 6, Alabama, Florida, Georgia, and South Carolina: U.S. Geological Survey Hydrologic Investigation Atlas 730-G, 28 p.

Peck, M.F., McFadden, K.W., and Leeth, D.C., 2005, Effects of decreased ground-water withdrawals on ground-water levels and chloride concentrations in Camden County, Georgia, and ground-water levels in Nassau County, Florida, from September 2001 to May 2003: U.S. Geological Survey Scientific Investigations Report 2004-5295, 36 p.

Pierce, R.R., Barber, N.L., and Stiles, H.R., 1984, Georgia irrigation, 1970-80, a decade of growth: U.S. Geological Survey Water-Resources Investigations Report 83-4177, 29 p.

Purdum, E.D., and Penson, Georgann, 1998, Northwest Florida Water Management District, in Fernald, E.A., and Purdum, E.D., Water resources atlas of Florida: Florida State University, Institute of Science and Public Affairs, p. 170-193.
Reese, R.S., 2002, Inventory and review of aquifer storage and recovery in southern Florida: U.S. Geological Survey Water Resources Investigations Report 02-4036, 56 p.

Renken, R.A., 1998, Ground water atlas of the United States, Segment 5, Arkansas, Louisiana, Mississippi: U.S. Geological Survey Hydrologic Investigation Atlas 730-F, 28 p.

St. Johns River Water Management District, 2004, Water use in the St. Johns River Water Management District, 2000: Palatka, Technical Fact Sheet SJ2004-FS1, 6 p.

Sepúlveda, Nicasio, 2002, Simulation of ground-water flow in the intermediate and Floridan aquifer systems in peninsular Florida: U.S. Geological Survey WaterResources Investigations Report 02-4009, 130 p.

Scott, T.M., Means, G.H., Meegan R.P., Upchurch, S.B., Copeland, R.E., Jones, James, Roberts, Tina, and Willet, Alan, 2004, Springs of Florida: Florida Geological Survey Bulletin Number 66, 377 p.

Solley, W.B., Pierce, R.R., and Perlman, H.A., 1998, Estimated use of water in the United States in 1995: U.S. Geological Survey Circular 1200, 71 p.

Southwest Florida Water Management District, 2002, Estimated water use in the Southwest Florida Water Management District, 2000: Brooksville, Resource Conservation and Development Department, Conservation Projects Section, $151 \mathrm{p}$.

Spechler, R.M., and Schiffer, D.M., 1995, Springs of Florida: U.S. Geological Survey Fact Sheet FS-151-95, 2 p.

U.S. Geological Survey, 2003, Principal aquifers of the United States, The National atlas of the United States: U.S. Geological Survey, scale 1:5,000,000, 1 sheet.

University of Nebraska, 2004, National drought summaries January 4-December 26, 2000: accessed February 19, 2004, http://www.drought.unl.edu/dm/ archive/2000. 